\title{
Sources and contributions of wood smoke during winter in London: assessing local and regional influences
}

\author{
L. R. Crilley ${ }^{1}$, W. J. Bloss ${ }^{1}$, J. Yin ${ }^{1}$, D. C. S. Beddows ${ }^{1, *}$, R. M. Harrison ${ }^{1, * *}$, J. D. Allan ${ }^{2, *}$, D. E. Young, ${ }^{2, * * *}$, M. Flynn ${ }^{2}$, \\ P. Williams ${ }^{2, *}$, P. Zotter ${ }^{3, * * *}$, A. S. H. Prevot ${ }^{3}$, M. R. Heal ${ }^{4}$, J. F. Barlow ${ }^{5}$, C. H. Halios ${ }^{5}$, J. D. Lee ${ }^{6}$, S. Szidat ${ }^{7}$, and \\ C. Mohr $^{8, * * * * *}$ \\ ${ }^{1}$ School of Geography, Earth and Environmental Sciences, University of Birmingham, Edgbaston, Birmingham, B15 2TT, UK \\ ${ }^{2}$ School of Earth, Atmospheric and Environmental Sciences, University of Manchester, Manchester, UK \\ ${ }^{3}$ Laboratory of Atmospheric Chemistry, Paul Scherrer Institute (PSI), 5232 Villigen PSI, Switzerland \\ ${ }^{4}$ School of Chemistry, University of Edinburgh, Edinburgh, UK \\ ${ }^{5}$ Department of Meteorology, University of Reading, Reading, UK \\ ${ }^{6}$ Department of Chemistry, University of York, York, UK \\ ${ }^{7}$ Department of Chemistry and Biochemistry and Oeschger Centre of Climate Change Research, \\ University of Bern, Bern, Switzerland \\ ${ }^{8}$ Department of Atmospheric Sciences, University of Washington, Seattle, Washington 98195, USA \\ *also at: National Centre for Atmospheric Science, UK \\ **also at: Department of Environmental Sciences/Center of Excellence in Environmental Studies, \\ King Abdulaziz University, Jeddah 21589, Saudi Arabia \\ **** now at: Department of Environmental Toxicology, University of California, Davis, CA 95616, USA \\ ***** now at: Lucerne School of Engineering and Architecture, Bioenergy Research, \\ Lucerne University of Applied Sciences and Arts, 6048 Horw, Switzerland \\ ****** now at: Institute for Meteorology and Climate Research, Atmospheric Aerosol Research, \\ Karlsruhe Institute of Technology, Karlsruhe, Germany
}

Correspondence to: R. M. Harrison (r.m.harrison@bham.ac.uk)

Received: 11 August 2014 - Published in Atmos. Chem. Phys. Discuss.: 31 October 2014

Revised: 13 February 2015 - Accepted: 26 February 2015 - Published: 20 March 2015

\begin{abstract}
Determining the contribution of wood smoke to air pollution in large cities such as London is becoming increasingly important due to the changing nature of domestic heating in urban areas. During winter, biomass burning emissions have been identified as a major cause of exceedances of European air quality limits. The aim of this work was to quantify the contribution of biomass burning in London to concentrations of $\mathrm{PM}_{2.5}$ and determine whether local emissions or regional contributions were the main source of biomass smoke. To achieve this, a number of biomass burning chemical tracers were analysed at a site within central London and two sites in surrounding rural areas. Concentrations of levoglucosan, elemental carbon (EC), organic carbon (OC) and $\mathrm{K}^{+}$were generally well correlated across the three sites. At all the sites, biomass burning was found to be a source
\end{abstract}

of $\mathrm{OC}$ and $\mathrm{EC}$, with the largest contribution of EC from traffic emissions, while for $\mathrm{OC}$ the dominant fraction included contributions from secondary organic aerosols, primary biogenic and cooking sources. Source apportionment of the $\mathrm{EC}$ and $\mathrm{OC}$ was found to give reasonable estimation of the total carbon from non-fossil and fossil fuel sources based upon comparison with estimates derived from ${ }^{14} \mathrm{C}$ analysis. Aethalometer-derived black carbon data were also apportioned into the contributions from biomass burning and traffic and showed trends similar to those observed for EC. Mean wood smoke mass at the sites was estimated to range from 0.78 to $1.0 \mu \mathrm{g} \mathrm{m}^{-3}$ during the campaign in January-February 2012. Measurements on a $160 \mathrm{~m}$ tower in London suggested a similar ratio of brown to black carbon (reflecting wood burning and traffic respectively) in regional and London air. 
Peaks in the levoglucosan and $\mathrm{K}^{+}$concentrations were observed to coincide with low ambient temperature, consistent with domestic heating as a major contributing local source in London. Overall, the source of biomass smoke in London was concluded to be a background regional source overlaid by contributions from local domestic burning emissions. This could have implications when considering future emission control strategies during winter and may be the focus of future work in order to better determine the contributing local sources.

\section{Introduction}

A number of detrimental health effects have been associated with exposure to airborne particles (Cohen et al., 2005; Kampa and Castanas, 2008). Therefore, identifying the sources contributing to air pollution is desirable in order to implement effective control strategies to reduce the health burden associated with ambient particles. In an urban environment, the major primary sources of ambient particles are typically road traffic, industrial emissions and biomass burning (Viana et al., 2008). Of these primary sources, biomass burning is perhaps the more difficult to apportion or quantify as its source profile is not well defined due to the large variation in actual sources that alter the chemical nature of the emitted particles. These sources can include natural wild fires and domestic heating, which will further vary depending on the heating device used (e.g. stove or fireplace) and the type of wood burned (Schauer et al., 2001; Simoneit, 2002; Heringa et al., 2011).

A number of techniques have been developed to determine the contribution of biomass burning to the total levels of ambient particles. These techniques include the chemical analysis of filter samples for elemental carbon (EC) and organic carbon (OC) (Gelencsér et al., 2007), the radioisotope of carbon $\left({ }^{14} \mathrm{C}\right.$; Heal, 2014; Heal et al., 2011; Szidat et al., 2006) and chemical tracers such as levoglucosan and potassium (Harrison et al., 2012a; Viana et al., 2013; Wagener et al., 2012). Instruments such as aethalometers (Sandradewi et al., 2008a, b; Herich et al., 2011) and aerosol mass spectrometers (Allan et al., 2010; Lanz et al., 2010; Crilley et al., 2014) have also been useful for determining the contribution of biomass burning with the added advantage of measurements at a high time resolution. Using these techniques, analytical methods have been utilised to separate biomass burning from other urban sources, such as vehicle emissions, and so provide a quantitative estimate of the contribution of biomass burning to the overall particle load. Recent work has shown that the contribution of biomass burning to the OC fraction in an urban environment derived from radiocarbon, levoglucosan and aerosol mass spectrometry results gave similar estimates, ranging from 0.3 to $0.7 \mu \mathrm{g} \mathrm{m}^{-3}$, and indicates that these techniques can give comparable results (Minguillón et al., 2011).

Alternatively, indirect measurements of wood smoke may be obtained using either a two-wavelength $(2 \mathrm{~W} \mathrm{AE})$ or seven-wavelength (7W AE) aethalometer. However, the reliability of wood smoke and traffic contribution estimations obtained from aethalometers has been called into question, particularly for locations with low concentrations of wood smoke (Harrison et al., 2012a, 2013). Estimating the contribution of biomass burning relies on the enhanced UV absorption of wood smoke relative to traffic emitted particles, as detected by an aethalometer. Using an aethalometer, the difference between the UV wavelength channel $(370 \mathrm{~nm})$ and the $880 \mathrm{~nm}$ channel gives a measure of UV absorbing particulate matter (UVPM) that has demonstrated strong correlation with levoglucosan and hence been suggested as a qualitative tracer for biomass burning (Wang et al., 2011a, b). For a seven-wavelength aethalometer, a two-component model has been proposed that can separate out the traffic and wood burning contributions using two different wavelength channels (Sandradewi et al., 2008a, b). However, the model relies on two assumptions: (1) only traffic and wood burning contribute to the absorption and (2) absorption Ångstrom exponents $(\alpha)$ for both sources can be assigned a priori. Single $\alpha$ values are assumed for each source in this model even though they can vary substantially, especially $\alpha$ for wood burning (Harrison et al., 2013). Thus the application of multiple techniques can enhance confidence in the estimated contributions of biomass burning to the ambient particle mass concentrations.

Determining the contribution of wood smoke in large urban centres such as London is becoming increasingly important due to the changing nature of domestic heating. In the UK for example, over the last few decades the influence of wood smoke upon urban air quality has been thought to have been minimal due to natural gas being the main combustion fuel used for domestic heating. However, this is changing partly due to the installation of biomass burning boilers to meet renewable energy targets and also a rise in socalled recreational burning for aesthetic reasons (Fuller et al., 2013). Recent work in large urban centres (London, Paris and Berlin) has demonstrated an increase in the contribution of wood smoke to ambient particles during winter that can at times exceed traffic emissions (Crippa et al., 2013; Fuller et al., 2013, Wagener et al., 2012). With measures such as low emission zones reducing the impact of traffic emissions in urban centres (see e.g. Qadir et al., 2013), wood smoke is becoming relatively more important to the overall ambient particle concentration, particularly during winter (Fuller et al., 2014). In Europe, biomass burning has been identified as a major cause of exceedances of European air quality limits during winter (Fuller et al., 2013; Reche et al., 2011).

In light of the changing nature of emissions in urban areas, there is a need for on-going measurements to assess the impact of biomass burning in cities like London. There- 
fore we aimed to determine quantitatively the contribution of biomass burning in London and surrounding rural areas. As a consequence of the challenges in apportioning biomass burning, a number of different methods and instruments were used and compared in the current work. This work also aimed to compare the concentrations between London and rural sites and determine whether local emissions or regional sources were the main source of biomass smoke in London.

\section{Method}

\subsection{Sampling sites}

The measurements for this paper were conducted as a part of the NERC-funded ClearfLo project (Clean Air for London, www.clearflo.ac.uk), to investigate boundary layer pollution in London. An overview of the project can be found in Bohnenstengel et al. (2014). Four sites were selected for chemical sampling in this particular study: an urban background and an elevated site within London and two sites in surrounding rural areas, with details summarised in the following sections. Site locations are shown in Fig. 1. Furthermore, additional measurements with a scanning Doppler lidar were also conducted for this study at sites within central London as indicated in Fig. 1. Details on the lidar measurements performed can be found in Sect. 2.2.3.

\subsubsection{North Kensington (NK), London}

The North Kensington site is located within the grounds of a school in a residential area $\left(51^{\circ} 31^{\prime} 15^{\prime \prime} \mathrm{N}, 0^{\circ} 12^{\prime} 49^{\prime \prime} \mathrm{W}\right)$ and is classified as urban background. Central London lies $7 \mathrm{~km}$ to the east and a major road is located approximately $500 \mathrm{~m}$ to the south of the site. A more complete description of the site and air pollution climate is available in Bigi and Harrison (2010); the site is considered representative of the background air quality within much of London. This site is part of the Automatic Urban and Rural Network (AURN), with further details on the instrumentation and sampling procedures available in Sect. 2.2.

\subsubsection{Detling, Kent}

This is a rural site located in the Detling show grounds, approximately $45 \mathrm{~km}$ south-east of central London $\left(51^{\circ} 18^{\prime} 7^{\prime \prime} \mathrm{N}, 0^{\circ} 35^{\prime} 22^{\prime \prime} \mathrm{E}\right)$ and is bordered by fields. To the south of the site, approximately $150 \mathrm{~m}$, lies a busy road; the closest village (Detling) is to the south-west (approximately $1.5 \mathrm{~km}$ ). The winter campaign site, approximately $800 \mathrm{~m}$ to the south of the AURN site, was not co-located with the longterm AURN monitoring site (Mohr et al., 2013).

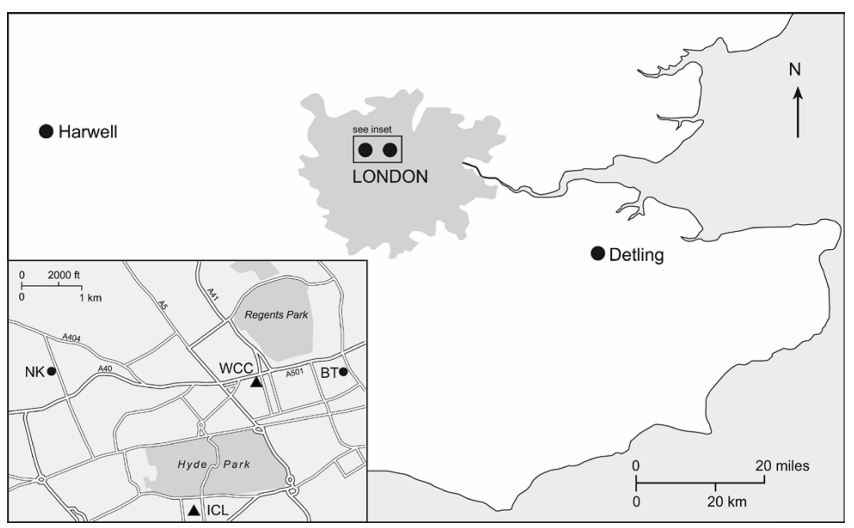

Figure 1. Map of the study area with the sampling sites (indicated with circles) and lidar locations (designated with triangles) indicated. Note for the start of the winter IOP the lidar operated from the Westminster City Council (WCC) building and then moved to Imperial College London (ICL). During the summer IOP the lidar operated from the North Kensington (NK) site.

\subsubsection{Harwell, Oxfordshire}

The second rural site was located approximately $80 \mathrm{~km}$ west of central London within the Harwell Science Centre $\left(51^{\circ} 34^{\prime} 16^{\prime \prime} \mathrm{N}, 1^{\circ} 19^{\prime} 31^{\prime \prime} \mathrm{W}\right)$ and is part of the AURN. The closest village, Chilton, and the nearest main road (A34) are about $2 \mathrm{~km}$ to the east of the site. The site is surrounded by fields and is considered as representative of a rural location (Charron et al., 2007).

\subsubsection{British Telecom (BT) Tower, London}

The elevated site utilised in this study was the BT tower $\left(51^{\circ} 31^{\prime} 17.31^{\prime \prime} \mathrm{N} ; 0^{\circ} 8^{\prime} 20.12^{\prime \prime} \mathrm{W}\right)$ located at 60 Cleveland St. in London. The main platform for the aethalometer was a well-ventilated balcony (level T35, $160 \mathrm{~m}$ above ground level), and the gas monitors were sampled from a height of approximately $180 \mathrm{~m}$ above ground level $\left(\mathrm{CO}\right.$ and $\left.\mathrm{NO}_{\mathrm{x}}\right)$. Further description of the BT site can be found in Harrison et al. (2012b).

\subsection{Sampling methodology and instrumentation}

In this study two data sets were collected, comprising a winter campaign and long-term measurements. The winter campaign was part of the winter intensive observation period (IOP) within the ClearfLo project, which ran from 6 January 2012 to 16 February 2012. The winter campaign included both filter sampling and aethalometer measurements at Detling, NK and Harwell. Long-term measurements with an aethalometer and gas monitors were conducted at the BT tower and NK from 24 January 2012 to 24 June 2013. Details of the sampling methods for these two data sets are summarised in the following sections. 
Table 1. Summary of sampling methodology for the filter analyses in the winter campaign. Note NA means not available.

\begin{tabular}{|c|c|c|c|c|c|}
\hline & & Levoglucosan & $\mathrm{K}^{+}$ & $\mathrm{OC} / \mathrm{EC}$ & ${ }^{14} \mathrm{C}$ \\
\hline \multirow{4}{*}{ Harwell } & Size fraction & $\mathrm{PM}_{2.5}$ & $\mathrm{PM}_{2.5}$ & $\mathrm{PM}_{2.5}$ & NA \\
\hline & Sampling interval & $24 \mathrm{~h}$ & $24 \mathrm{~h}$ & $24 \mathrm{~h}$ & \\
\hline & Start time & Noon & Noon & Noon & \\
\hline & Dates & $12 / 01-9 / 02$ & $12 / 01-9 / 02$ & $12 / 01-9 / 02$ & \\
\hline \multirow{4}{*}{ NK } & Size fraction & $\mathrm{PM}_{2.5}$ & $\mathrm{PM}_{2.5}$ & $\mathrm{PM}_{2.5}$ & $\mathrm{PM}_{2.5}$ \\
\hline & Sampling interval & $24 \mathrm{~h}$ & $24 \mathrm{~h}$ & $24 \mathrm{~h}$ & $24 \mathrm{~h}$ \\
\hline & Start time & Noon & Noon & Noon & Noon \\
\hline & Dates & $12 / 01-8 / 02$ & $12 / 01-8 / 02$ & $12 / 01-8 / 02$ & $31 / 01-07 / 02$ \\
\hline \multirow{4}{*}{ Detling } & Size fraction & $\mathrm{PM}_{10}$ & NA & $\mathrm{PM}_{1}$ & $\mathrm{PM}_{1}$ \\
\hline & Sampling interval & $24 \mathrm{~h}$ & NA & $24 \mathrm{~h}$ & $24 \mathrm{~h}$ \\
\hline & Start time & Midnight & NA & Midnight & Midnight \\
\hline & Dates & $12 / 01-9 / 02$ & NA & $12 / 01-9 / 02$ & $12 / 01-9 / 02$ \\
\hline
\end{tabular}

\subsubsection{Winter campaign measurements}

During the winter campaign, filter samples were collected for the chemical analysis of selected biomass burning tracers. Due to various logistical reasons, the sampling regimes for the different filter and instrumental analysis utilised in this paper were not all run at the same time or over the same sampling interval and the filter sampling and analysis methods are summarised in Table 1. The levoglucosan sampling was similar at NK and Harwell but differed at Detling in terms of the size fraction collected and sampling start time (Table 1). A Digitel DHA-80 sampler was used at the NK and Harwell sites to collect $\mathrm{PM}_{2.5}$ particles on $150 \mathrm{~mm}$ diameter quartz fibre filter circles over a $24 \mathrm{~h}$ sampling period. These filters were analysed for levoglucosan, total OC, EC, $\mathrm{K}^{+}$and ${ }^{14} \mathrm{C}$ (the last only applies for NK). At Detling aerosols were collected on pre-baked quartz fibre filters (PALL 2500QATUP Tissuquartz) using a high-volume sampler (CAV-A/MSb) with a $\mathrm{PM}_{1}$ inlet, a flow rate of $500 \mathrm{~L} \mathrm{~min}^{-1}$ and a sampling time of $24 \mathrm{~h}$. These filters were analysed for EC, OC and ${ }^{14} \mathrm{C}$ in the total carbon (TC) fraction. Separate filter samples with a $\mathrm{PM}_{10}$ inlet were collected for levoglucosan analysis.

The different size fraction analysed for levoglucosan at Detling compared to the other sites is unlikely to affect the results as most of the particle-associated levoglucosan is generally within the $\mathrm{PM}_{2.5}$ (Saarikoski et al., 2008; Wagener et al., 2012; Yttri et al., 2005). Potassium samples were collected at Detling as a part of this project but failed quality control and therefore were not included in the current work.

In addition to the filter samples collected, measurements of BC were conducted using a Magee Scientific sevenwavelength aethalometer (model AE-31) at NK and Detling during the winter campaign. At NK, the seven-wavelength aethalometer sampled continuously with a 5 min sampling interval, while at Detling the $7 \mathrm{~W}$ AE sampled at a different sampling interval of 2 min. Furthermore, at NK the $7 \mathrm{~W}$ AE also sampled during the ClearfLo summer IOP
(21 July 2012-23 August 2012) with a 5 min sampling interval.

As Harwell, NK and Detling are part of the AURN, BC and $\mathrm{PM}_{2.5}$ concentrations were obtained from instruments in this network for the winter campaign. $\mathrm{PM}_{2.5}$ mass concentrations were determined by the Filter Dynamic Measurement System method at an hourly interval and were subjected to the AURN network quality control procedures (RicardoAEA, 2013). In addition to the $7 \mathrm{~W}$ AE, data from a twowavelength aethalometer (Magee Scientific, model AE 22) were also collected at 15 min intervals at each AURN site.

\subsubsection{Long-term measurements}

At the BT tower, measurements of $\mathrm{BC}$ were performed by a 7W AE (Magee Scientific, model AE-30), while concentrations of $\mathrm{NO}$ and $\mathrm{NO}_{2}$ were analysed by chemiluminescence (Ecophysics, model 780TR fitted with photolytic blue light converter (BLC) for $\mathrm{NO}_{2}$ ), all at a 5 min sampling interval. Calibration was carried out using a 5 ppm NO in nitrogen gas standard, diluted to $50 \mathrm{ppb}$ in $\mathrm{NO}_{\mathrm{x}}$ free air. Calibration of the BLC conversion efficiency was done using gas phase titration of the NO calibration gas with ozone. An Aero-Laser fast carbon monoxide analyser (model AL5002) at a $10 \mathrm{~Hz}$ sampling rate was used at the BT tower to measure the concentration of $\mathrm{CO}$. As $7 \mathrm{~W}$ AE data were only available for limited periods at NK compared to BT tower, two-wavelength aethalometer data from the AURN network were also obtained at NK, along with concentrations of $\mathrm{CO}, \mathrm{NO}$ and $\mathrm{NO}_{2}$ from 1 January 2012 to 30 June 2013.

\subsubsection{Meteorological measurements}

Meteorological data were obtained from the Met Office for three sites that were judged to be the most suitable based upon relative location to the sampling sites. For NK and BT tower, wind data from Heathrow airport station were used as this site will not be affected by large buildings. The Met Of- 
fice stations Benson and Gravesend were used for Harwell and Detling respectively, which were the closest stations geographically with wind data. Benson is approximately $16 \mathrm{~km}$ to the east of Harwell and Gravesend about $20 \mathrm{~km}$ northwest of Detling. The meteorological data obtained from the Met Office had a $1 \mathrm{~h}$ time resolution. The approximate times of sunrise and sunset throughout the winter campaign were 07:40 and 16:45 UT (and local time).

During the ClearfLo summer and winter IOPs, a scanning Doppler lidar (Halo Photonics Streamline) was used for monitoring the boundary layer depth and structure, with the locations shown in Fig. 1. The lidar operates at $1.5 \mu \mathrm{m}$ wavelength, integrated signals are outputted every $3.6 \mathrm{~s}$ and the vertical resolution is $30 \mathrm{~m}$. For the first part of the winter IOP period (6-11 January 2012) the lidar was operating on the rooftop of the Westminster City Council's building (WCC, $18 \mathrm{~m}$ a.g.1., $51^{\circ} 31^{\prime} 17^{\prime \prime} \mathrm{N}, 0^{\circ} 09^{\prime} 40^{\prime \prime} \mathrm{W}$ ) before it was moved to the engineering building at Imperial College London (ICL, $33 \mathrm{~m}$ a.g.l., $51^{\circ} 29^{\prime} 55^{\prime \prime} \mathrm{N}, 0^{\circ} 10^{\prime} 29^{\prime \prime} \mathrm{W}$ ), where it was operating until 8 February 2012. For the summer IOP period an identical lidar was operating at NK (ground level, $51^{\circ} 31^{\prime} 15^{\prime \prime} \mathrm{N}, 00^{\circ} 12^{\prime} 49^{\prime \prime} \mathrm{W}$ ) with a gate resolution of $18 \mathrm{~m}$. The mixing height was detected as the level where the vertical velocity variance measured with the lidar drops below a threshold value, following the method described in Barlow et al. (2014) and originally proposed by Barlow et al. (2011). The minimum observable height is different for each location and depends on the lidar gate and the height that the instrument is placed (above ground level) at each site. Thus it is $124 \mathrm{~m}$ for WCC, $139 \mathrm{~m}$ for ICL and $63 \mathrm{~m}$ for NK ; all heights are measured above ground level. Long-term meteorological measurements were conducted at the top of BT tower (190.8 ma.g.1.), employing an instrumentation platform equipped with an eddy covariance system (Gill Instruments R3-50 sonic anemometer, and Licor Li-7500 Hygrometer), a net radiometer (CNR4, Kipp \& Zonen) and a weather station (Vaisala WXT520).

\subsection{Chemical analysis}

\subsubsection{Levoglucosan}

The analytical method applied is similar to that described in Yin et al. (2010) and Wagener et al. (2012) but modified for the detection of levoglucosan. In brief, one-quarter of the quartz fibre filter sample was spiked with an internal standard (IS), methyl beta-D-xylopyranoside (Sigma-Aldrich Ltd) and extracted with dichloromethane and methanol under mild sonication at room temperature. The combined extracts were filtered and concentrated down to $50 \mu \mathrm{L}$. One aliquot of the extract was evaporated until nearly dry, derivatized by the addition of N,O-bis(trimethylsilyl)trifluoroacetamide plus $1 \%$ trimethylchlorosilane (BSTFA $+1 \%$ TMCS) and pyridine at $70^{\circ} \mathrm{C}$ for $1 \mathrm{~h}$ and finally cooled in a desiccator. The quantification was based on the IS and a six-point authentic standard calibration curve, with selected ion monitoring mode on an Agilent GC-MS instrument. The ions monitored were $\mathrm{m} / \mathrm{z}$ 204 and 217 for the IS and $m / z$ 204, 217 and 333 for levoglucosan.

\subsubsection{Elemental and organic carbon}

The quartz fiber filter samples from NK, Harwell and Detling were also analysed for OC and EC by a Sunset thermaloptical carbon analyser (Sunset Laboratory Inc.). The protocol used was the EUSAAR 2 protocol (Cavalli et al., 2010), in which organic carbon is removed during an initial nonoxidising temperature ramp from 200 to $650{ }^{\circ} \mathrm{C}$ under a helium atmosphere, and then a second temperature ramp from 500 to $850^{\circ} \mathrm{C}$ is initialised with the carrier gas switched to a helium/oxygen mixture for removing elemental carbon and organic carbon pyrolysis products.

\subsubsection{Radiocarbon $\left({ }^{14} \mathrm{C}\right)$}

\section{Detling}

Sample preparation for the ${ }^{14} \mathrm{C}$ analysis was performed with two different techniques. First, TC was isolated before the ${ }^{14} \mathrm{C}$ analysis using the THEODORE system (see Szidat et al., 2004, for more details). In brief, TC is oxidised to $\mathrm{CO}_{2}$ from filter punches with at $650^{\circ} \mathrm{C}$ for $12 \mathrm{~min}$ in an oxygen stream. The evolving $\mathrm{CO}_{2}$ is separated from interfering reaction gases, cryo-trapped and sealed in glass ampoules for ${ }^{14} \mathrm{C}$ measurements. Second, samples were also prepared following the approach described in Fahrni et al., 2010). Several small filter pieces are put in quartz tubes together with $\sim 0.25 \mathrm{~g}$ of copper oxide (small rods for elemental analysis, Fluka, Switzerland), evacuated, sealed and combusted for $4 \mathrm{~h}$ at $800^{\circ} \mathrm{C}$ in a muffle furnace (model LE 14/11/B150, Nabertherm, Germany).

The ${ }^{14} \mathrm{C}$ measurements were carried out using the MIni radio CArbon DAting System (MICADAS; Synal et al., 2007) at the Swiss Federal Institute of Technology (ETH) Zürich using a gas ion source (Ruff et al., 2007; Wacker et al., 2013), allowing the ${ }^{14} \mathrm{C}$ analysis of the gaseous $\mathrm{CO}_{2}$ without prior graphitisation (Ruff et al., 2010). Results from the ${ }^{14} \mathrm{C}$ measurement are expressed as fraction of modern $\left(f_{\mathrm{M}}\right)$, denoting the ratio of the ${ }^{14} \mathrm{C} /{ }^{12} \mathrm{C}$ content of the samples related to the ${ }^{14} \mathrm{C} /{ }^{12} \mathrm{C}$ ratio in 1950 , defined as 0.95 times the value of the standard SRM4990B (Stuiver and Polach, 1977). The $f_{M}$ values were corrected for $\delta^{13} \mathrm{C}$ fractionation (Wacker et al., 2010) and for the ${ }^{14} \mathrm{C}$ decay between 1950 and the year of measurement. Furthermore, a mass depending blank correction was applied following an isotopic mass balance as presented by Zapf et al. (2013). The obtained blank mass and $f_{\mathrm{M}}$ of TC were $0.53 \pm 0.18$ and $0.50 \pm 0.17 \mu \mathrm{g} \mathrm{cm}^{-2}$ respectively. To account for the excess ${ }^{14} \mathrm{C}$ from the thermonuclear weapon tests in the late 1950s and early 1960s, the blank corrected $f_{\mathrm{M}}$ values were converted into non-fossil fractions 
using a reference value $\left(f_{\mathrm{NF}, \text { ref }}=1.082 \pm 0.04\right)$ representing the modern ${ }^{14} \mathrm{C}$ content of biogenic and biomass burning aerosols during the sampling period compared to 1950 before the bomb testing (see e.g. Zotter et. al., 2014a).

\section{North Kensington}

Each filter of $\mathrm{PM}_{2.5}$ was equally divided. The percent modern carbon $\left(f_{\mathrm{M}}\right)$ in TC was derived from one-half of the filter sample through the following two-step combustion, similar to that described in Heal et al. (2011) and using the same quality assurance procedures. Filters were first combusted in high purity $\mathrm{O}_{2}$ at $375^{\circ} \mathrm{C}$ for $1 \mathrm{~h}$ and then combusted in high purity $\mathrm{O}_{2}$ at $800^{\circ} \mathrm{C}$ for $4 \mathrm{~h}$, with collection of the evolved $\mathrm{CO}_{2}$ from each combustion. In both cases the $\mathrm{CO}_{2}$ was subject to offline clean up, graphitisation and AMS determination of $f_{\mathrm{M}}$. The $f_{\mathrm{M}}$ (TC) was calculated by mass balance of the two subsamples. This was converted to fraction contemporary carbon by dividing by a value that assumes an average age for the material comprising the contemporary carbon. Here a divisor of 1.08 was used, as discussed in Heal et al. (2011).

\subsubsection{Potassium}

Small pieces of the quartz filters collected at Harwell and NK were extracted with distilled deionised water $(5 \mathrm{~mL})$ by undergoing $40 \mathrm{~min}$ mechanical agitation. The resulting solutions were filtered with $32 \mathrm{~mm}$ Acrodisc syringe filter $(0.2 \mu \mathrm{m}$ pore size $)$ and analysed for $\mathrm{K}^{+}$with a Dionex DX500 system, which uses a GP-40 gradient pump, but run with isocratic elution using $15.4 \mathrm{mM}$ MSA $\left(\mathrm{CH}_{3} \mathrm{SO}_{3} \mathrm{H}\right)$ as eluent. The sample concentrations were calibrated with a series of mixed standards of known concentration (0.01-10 ppm).

\subsection{Data analysis}

Rose plots, diurnal variations and conditional probability function (CPF) analyses were all performed in R using the Openair package (Carslaw and Ropkins, 2012). CPF is a data analysis tool for finding the direction of source contributions and was applied to the aethalometer and gas species data sets as they had the necessary high time resolution. The difference in time intervals between meteorological and the pollutant data meant that the hourly averaged aethalometer and gas species data were used. CPF analysis is presented here in the form of polar plots, which plot the number of events during which the concentration was greater than the 90th percentile as a function of both wind speed and direction. As a result, CPF polar plots present the probability that high concentrations of a pollutant came from a particular wind direction and speed (Carslaw, 2014) and can give information on the contributions from local and regional sources. One-way analysis of variance (ANOVA) was used to compare mean values and was calculated in SPSS v19. Pearson's correlations between the chemical species were calculated in SPSS using hourly or daily concentrations as appropriate to the technique. Due to the different sampling start times at Detling (midnight) to the other sites (noon) for levoglucosan, EC, OC and ${ }^{14} \mathrm{C}$, the concentrations for consecutive days at Detling were averaged to enable comparison between the sites.

\subsubsection{Source apportionment of the OC and EC}

A number of analytical methods were employed for apportioning the contribution of fossil fuel and biomass burning emissions to the EC and OC fractions. All methods assume that these two sources, biomass burning and fossil fuel emissions, are the sole sources of either EC or BC. The first method, referred to as the tracer method throughout this paper, is described in detail in Gelencsér et al. (2007). In this method, the primary OC concentration from biomass burning $\left(\mathrm{OC}_{\mathrm{bb}}\right)$ is estimated based on the concentration of levoglucosan and the ratio of levoglucosan to OC measured for biomass burning emissions from the literature. The EC concentration from biomass burning $\left(\mathrm{EC}_{\mathrm{bb}}\right)$ is calculated from the $\mathrm{OC}_{\mathrm{bb}}$ using previously observed $\mathrm{OC} / \mathrm{EC}$ ratio for biomass burning emissions and the remainder of $\mathrm{EC}$ is apportioned to $\mathrm{EC}$ from fossil fuel emissions $\left(\mathrm{EC}_{\mathrm{ff}}\right)$. Primary $\mathrm{OC}$ from fossil fuel emissions $\left(\mathrm{OC}_{\mathrm{ff}}\right)$ is estimated using previously observed $\mathrm{OC} / \mathrm{EC}$ ratios for vehicle emissions. The remaining $\mathrm{OC}$ is from biogenic, cooking (both primary and secondary) or other secondary sources that can include secondary organic aerosols formed from fossil fuel combustion; this fraction is referred to as $\mathrm{OC}_{\mathrm{SOA}}$. One limitation of the tracer method is the assumption of constant source ratios, which may not have been the case throughout the current work. Furthermore, the value of these source ratios for vehicle emissions and biomass burning (both levoglucosan / OC and OC /EC) are dependent on the combustion conditions and fuel type. As a consequence, a wide range of ratios have been previously reported in the literature for vehicle emissions (e.g. El Haddad et al., 2013; Gelencsér et al., 2007; Pio et al., 2011) and for biomass burning (e.g. Gelencsér et al., 2007; Schmidl et al., 2008), and thus there is uncertainty regarding the correct source ratios for emissions at the sites. In this study, we have initially applied the average source ratios for Europe as reported in Gelencsér et al. (2007). As a result of the uncertainty regarding the correct source ratios for biomass burning and vehicle emissions, a sensitivity study was carried out using a range of source ratios from the literature to assess the variability in the source apportionment.

Further source apportionment of the total carbon (sum of EC and OC concentration) was carried out using the radioisotope of carbon $\left({ }^{14} \mathrm{C}\right)$ concentrations as described in Heal at al. (2011). In this method, the TC is apportioned based on whether carbon had a fossil $\left(\mathrm{TC}_{\mathrm{ff}}\right)$ or contemporary (nonfossil, $\mathrm{TC}_{\mathrm{nf}}$ ) origin and will be referred to as the ${ }^{14} \mathrm{C}$ method throughout this paper. For comparison to the tracer method, the sum of $\mathrm{EC}_{\mathrm{ff}}$ and $\mathrm{OC}_{\mathrm{ff}}$ is considered equal to the $\mathrm{TC}_{\mathrm{ff}}$ while the $\mathrm{TC}_{\mathrm{nf}}$ is equivalent to the sum of $\mathrm{OC}_{\mathrm{SOA}}, \mathrm{OC}_{\mathrm{bb}}$ and 
$\mathrm{EC}_{\mathrm{bb}}$. This approach ignores the fact that some secondary $\mathrm{OC}$ is of fossil origin, although most published work indicates that the larger proportion is from biogenic (non-fossil) precursors. Secondary OC of fossil origin has been estimated to be $25 \pm 13 \%$ of secondary OC levels for several European cities in summer (Zotter et al., 2014a, and references therein). Recent results in the UK found that fossil EC and fossil OC comprised 27 and $20 \%$ of TC respectively (Heal et al., 2011). Using the average primary vehicle emissions OC / EC ratio of 0.58 (Gelencsér et al., 2007) the fraction of fossil OC from primary vehicle emissions was $15.7 \%$ of TC. This implies that fossil secondary OC was only around $4 \%$ of $\mathrm{TC}$ and therefore any differences in the calculated $\mathrm{TC}_{\mathrm{nf}}$, assuming that the $\mathrm{OC}_{\mathrm{SOA}}$ was totally non-fossil, would be within the uncertainties associated with the tracer method. As part of the sensitivity study reported in Sect. 3.3.1, inclusion of a $20 \%$ fossil fraction of secondary OC generated results which were still consistent with the ${ }^{14} \mathrm{C}$ data and within the variability of individual days. Furthermore, recent work by Charron et al. (2013) suggests a large biogenic contribution to SOA at southern UK sites.

\subsubsection{BC corrections and source apportionment}

The seven-wavelength aethalometer provides a real-time optical measurement of the light absorption $\left(b_{\text {abs }}\right)$ with seven different wavelengths $(370,470,520,590,660,880$ and $950 \mathrm{~nm}$ ) from which the equivalent black carbon concentration can be deduced (Petzold et al., 2013). Aethalometers suffer from various systematic errors e.g. multiple scattering by the filter fibres (scattering effect) and increased absorption by light-absorbing particles accumulating in the filter (shadowing or loading effect) (Bond et al., 1999; Liousse et al., 1993; Petzold et al., 1997). BC concentrations from the $2 \mathrm{~W}$ $\mathrm{AE}$ and $7 \mathrm{~W}$ AE were corrected for loading and scattering effects according to the procedure described in Weingartner et al. (2003). In the Weingartner correction a value of 1.2 was used for the loading correction, and the multiple scattering correction constant $(C)$ was determined based on comparison to results from a multi-angle absorption photometer (MAAP) at $630 \mathrm{~nm}$, as described in Collaud Coen et al. (2010). The results from this comparison determined a $C$ value of 3.336 and 3.095 for NK and Detling respectively. As there were no MAAP data available at Harwell or the BT tower, the average of the $C$ values determined at NK and Detling were applied to all $2 \mathrm{~W}$ and $7 \mathrm{~W}$ AE data to enable comparison between the sites. The mass absorption cross section, which is needed to convert the light absorption coefficient to $\mathrm{BC}$, was determined by plotting EC concentration (from thermal-optical analysis) against the corrected $880 \mathrm{~nm} b_{\text {abs }}$ at Detling, NK and Harwell. As there were no EC data at BT tower, the mass absorption cross section determined for NK was applied to the $\mathrm{BT}$ tower $7 \mathrm{~W}$ AE data. The $2 \mathrm{~W}$ AE mass absorption cross section values were calculated to be $7.3,8.1$ and $7.3 \mathrm{~m}^{2} \mathrm{~g}^{-1}$ for Harwell, NK and Detling respectively while a mass ab-

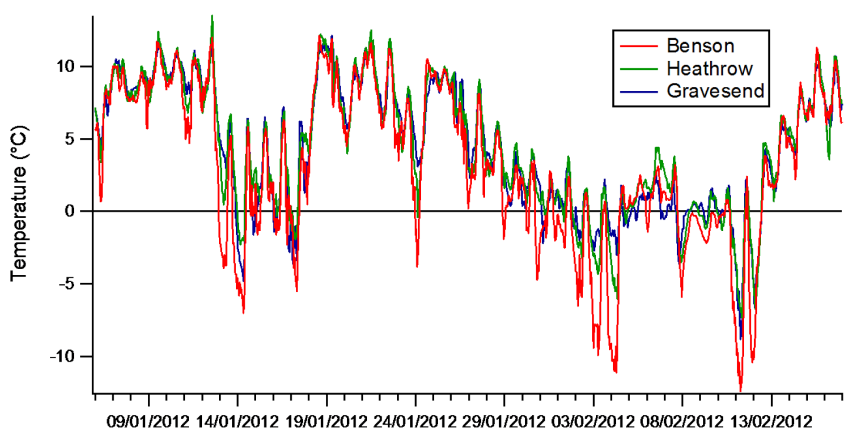

Figure 2. Time series of the temperature at three Met stations used for the entire winter campaign.

sorption cross section of $7.4 \mathrm{~m}^{2} \mathrm{~g}^{-1}$ was found for the $7 \mathrm{~W}$ $\mathrm{AE}$ at both NK and Detling.

Measurements from the $7 \mathrm{~W} \mathrm{AE}$ data were apportioned into the contribution from wood burning $\left(\mathrm{BC}_{\mathrm{wb}}\right)$ and traffic $\left(\mathrm{BC}_{\mathrm{tr}}\right)$ according to Sandradewi et al. (2008a, b), referred to as the aethalometer model. Aethalometer absorption values at 470 and $950 \mathrm{~nm}$ were used to determine $\mathrm{BC}_{\mathrm{wb}}$ and $\mathrm{BC}_{\mathrm{tr}}$ respectively, and an absorption Ångstrom exponent of 2 for wood smoke $\left(\alpha_{\mathrm{wb}}\right)$ and $1\left(\alpha_{\mathrm{tr}}\right)$ for traffic was used. As the UK AURN monitoring network employs $2 \mathrm{~W}$ AEs that measure at 370 and $880 \mathrm{~nm}$, UVPM (also referred to as delta- $C$ ) concentrations were also determined as UVPM has been proposed as a marker for wood smoke. UVPM concentration was calculated for both the $2 \mathrm{~W}$ and $7 \mathrm{~W}$ AE data by the difference of $\mathrm{BC}$ equivalent concentrations at 370 and $880 \mathrm{~nm}$ (Wang et al., 2011a, b). Furthermore for 7W AE data sets at the BT tower and NK, $\alpha$ for the total ambient absorbing particles was calculated using the 470 and $950 \mathrm{~nm}$ wavelength data according to the procedure described in Harrison et al. (2012a).

\section{Results and discussion}

\subsection{Meteorology}

Meteorological conditions were within expected seasonal variation for winter with low temperatures during the sampling period. Similar temperatures were observed at the three Met stations as demonstrated in Fig. 2. Wind rose plots for the winter IOP are given in the Supplement (Figs. S1-3), with Gravesend and Heathrow stations having similar plots, with the predominant wind direction being westerly. The wind rose plot for Benson differed slightly, with south-west winds being slightly more frequent and a stronger influence of winds from the south.

\subsection{Overall results from the filter samples at Harwell, NK and Detling (winter campaign)}

The summary statistics for the filter analysis results and the $\mathrm{BC}$ and $\mathrm{PM}_{2.5}$ concentrations are given in Table 2. Simi- 
Table 2. Summary statistics for selected species at Harwell, NK and Detling during the winter campaign. BC concentrations from a $2 \mathrm{~W}$ AE. Variability given for the average is 1 standard deviation. Note NA means not available.

\begin{tabular}{llll|llll}
\hline & & Levoglucosan & $\mathrm{K}^{+}$ & OC & EC & BC & $\mathrm{PM}_{2.5}$ \\
\hline \multirow{4}{*}{ Harwell } & & \multicolumn{2}{c}{$\mathrm{ng} \mathrm{m}^{-3}$} & \multicolumn{4}{c}{$\mu \mathrm{g} \mathrm{m}^{-3}$} \\
\cline { 3 - 8 } & Average & $92 \pm 51.6$ & $65 \pm 47$ & $2.3 \pm 1.8$ & $0.7 \pm 0.5$ & $0.7 \pm 0.6$ & \multicolumn{1}{c}{$14 \pm 11$} \\
& Range & $18.3-219$ & $7.9-189$ & $0.4-6.1$ & $0.03-2.2$ & $0.06-3.8$ & $0-63$ \\
& $n$ & 28 & 28 & 28 & 28 & 3131 & 831 \\
\hline \multirow{4}{*}{ NK } & Average & $77.6 \pm 35.9$ & $82.8 \pm 48.6$ & $3.5 \pm 2.2$ & $1.5 \pm 0.9$ & $1.4 \pm 1.3$ & $20 \pm 12$ \\
& Range & $27.8-155$ & $25-210$ & $1.0-8.6$ & $0.4-4.1$ & $0.07-15$ & $2-65$ \\
& $n$ & 27 & 27 & 27 & 27 & 3345 & 798 \\
\hline \multirow{4}{*}{ Detling } & Average & $69.7 \pm 62.7$ & NA & $2.2 \pm 1.6$ & $0.6 \pm 0.4$ & $0.9 \pm 0.8$ & $16 \pm 11$ \\
& Range & $5.5-264$ & & $0.3-5.9$ & $0.2-1.3$ & $0.07-5.0$ & $0-58$ \\
& $n$ & 28 & 26 & 26 & 2286 & 441 \\
\hline
\end{tabular}

lar average concentrations of levoglucosan were observed at the three sites but were notably higher compared to previous measurements in London and the UK (Harrison et al., 2012a). At NK, the mean levoglucosan concentration during the previous winter (2011) was $45 \mathrm{ng} \mathrm{m}^{-3}$ with a 90th percentile value of $69 \mathrm{ng} \mathrm{m}^{-3}$ (Harrison et al., 2012a), notably lower than the average of $77.6 \mathrm{ng} \mathrm{m}^{-3}$ observed in this study. In the current work, the average temperature for the sampling period was $4.4 \pm 4.4^{\circ} \mathrm{C}$ while during the 2011 sampling period (Harrison et al., 2012a) it was $6.3 \pm 3.1^{\circ} \mathrm{C}$, and this temperature difference was found to be statistically significant $(p>0.05)$ using one-way ANOVA. Thus the colder weather in 2012 may account for the observed higher concentrations of levoglucosan due to an increase in the levels of domestic heating coupled with potentially increased atmospheric stability. A similar relationship was observed in Switzerland (Zotter et al., 2014b). Overall, levoglucosan concentrations observed in the current work are at the lower end of previous winter observations across Europe for urban environments, which range from 40 to $570 \mathrm{ng} \mathrm{m}^{-3}$ in the $\mathrm{PM}_{2.5}$ fraction (Reche et al., 2012, and references therein). Domestic heating by wood burning is more common in mainland Europe than the UK and so would explain the observed lower levoglucosan concentrations in the UK (Harrison et al., 2012a). Levoglucosan emissions from biomass burning are also dependent on the burning conditions and type of fuel (Schauer et al., 2001; Simoneit, 2002; Heringa et al., 2011) and thus may also explain the observed lower concentrations in the UK.

The temporal variations in the concentration of levoglucosan, OC, EC and $\mathrm{K}^{+}$were similar at the sites, as demonstrated in Fig. 3, with peaks in concentration occurring on the same days. EC concentrations were well correlated between all three sites $\left(r^{2}>0.73\right)$ as were the concentration of OC $\left(r^{2}>0.82\right)$. Generally at the three sites the meteorology would be expected to be broadly similar owing to their close proximity and the strong correlation of concentrations over time points indicative of a possible regional source of carbonaceous aerosols at the sites, or similar local sources. The intra-site concentrations of levoglucosan and $\mathrm{K}^{+}$were correlated at Harwell and North Kensington $\left(r^{2}\right.$ of 0.62 at both sites), suggesting a common source. Levoglucosan concentrations at NK were well correlated with Harwell and Detling ( $r^{2}$ of 0.70 and 0.71 respectively), but between Harwell and Detling the concentrations were less correlated $\left(r^{2}\right.$ of 0.50$)$. That the concentrations of levoglucosan were at least moderately correlated between all the sites points to a common source at three sites. The weaker correlations between Harwell and Detling are probably a function of the greater intersite distance and hence greater variations in meteorological conditions and may also be related to local emissions.

It was also observed that periods of colder temperatures, such as 17-18 January and 2-4 February (Fig. 2), corresponded to peaks in the levoglucosan concentration (Fig. 3), especially at Harwell. This would implicate domestic heating as the main source, though it could also be due to greater atmospheric stability during these colder periods, resulting in reduced dispersion of the wood smoke (Reche et al., 2012). However, these colder periods (e.g. 2-4 February) did not necessarily equate to times of low wind speeds (Fig. S4, in the Supplement), suggesting that the levoglucosan concentrations were related more to changes in emissions. Overall, there appears to be a notable contribution from wood smoke and the sources are further investigated in Sect. 3.4.

\subsection{Contribution of traffic and biomass burning to carbonaceous aerosols (winter campaign)}

\subsubsection{Source apportionment of OC and EC}

Using the tracer method, contributions of biomass burning $\left(\mathrm{EC}_{\mathrm{bb}}\right.$ and $\left.\mathrm{OC}_{\mathrm{bb}}\right)$ and fossil fuel $\left(\mathrm{EC}_{\mathrm{ff}}\right.$ and $\left.\mathrm{OC}_{\mathrm{ff}}\right)$ to the $\mathrm{EC}$ and $\mathrm{OC}$ fractions were estimated first using the average of source ratios reported for Europe in Gelencsér et al. (2007). These applied source ratios for biomass burning were 0.136 

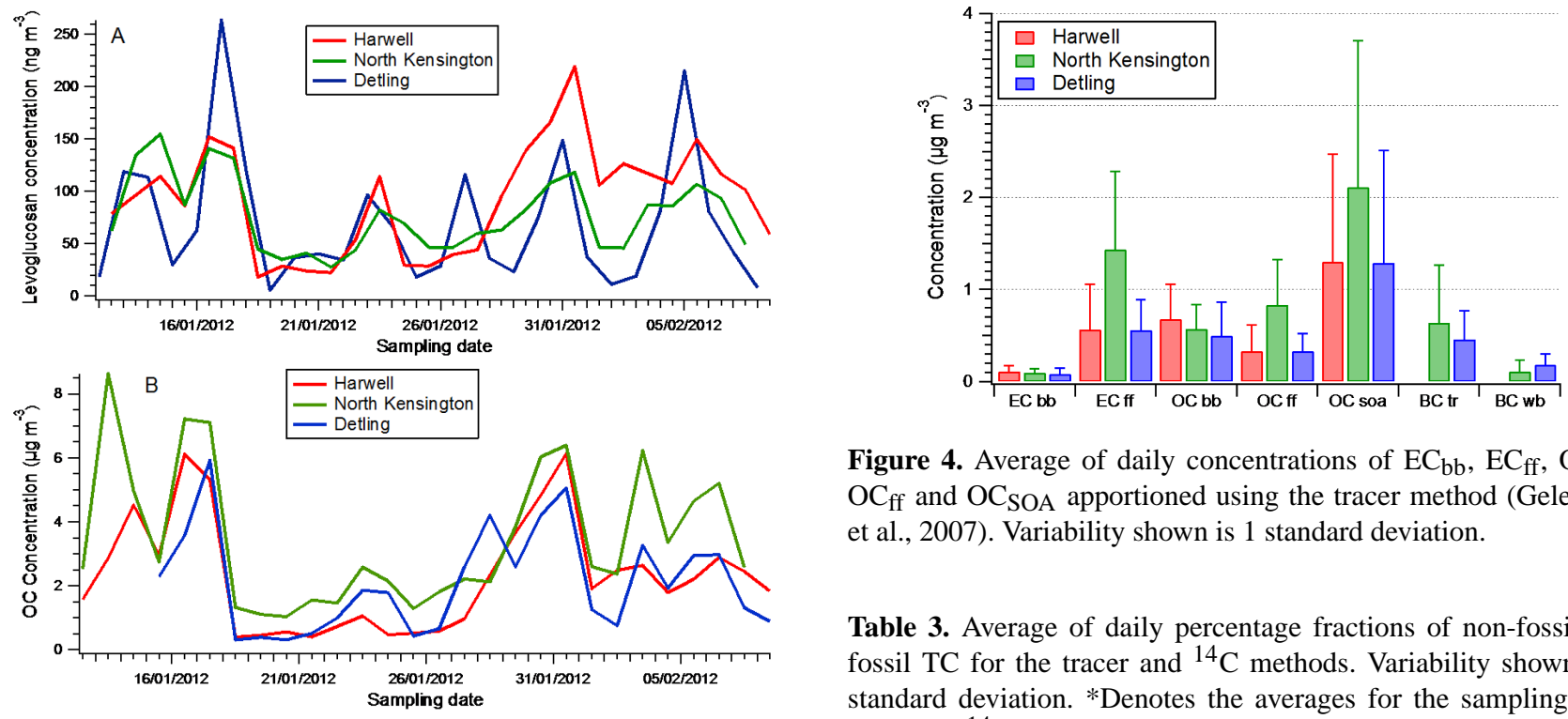

Figure 4. Average of daily concentrations of $\mathrm{EC}_{\mathrm{bb}}, \mathrm{EC}_{\mathrm{ff}}, \mathrm{OC}_{\mathrm{bb}}$, $\mathrm{OC}_{\mathrm{ff}}$ and $\mathrm{OC}_{\mathrm{SOA}}$ apportioned using the tracer method (Gelencsér et al., 2007). Variability shown is 1 standard deviation.

Table 3. Average of daily percentage fractions of non-fossil and fossil $\mathrm{TC}$ for the tracer and ${ }^{14} \mathrm{C}$ methods. Variability shown is 1 standard deviation. *Denotes the averages for the sampling days with both ${ }^{14} \mathrm{C}$ and $\mathrm{EC} / \mathrm{OC}$ data.

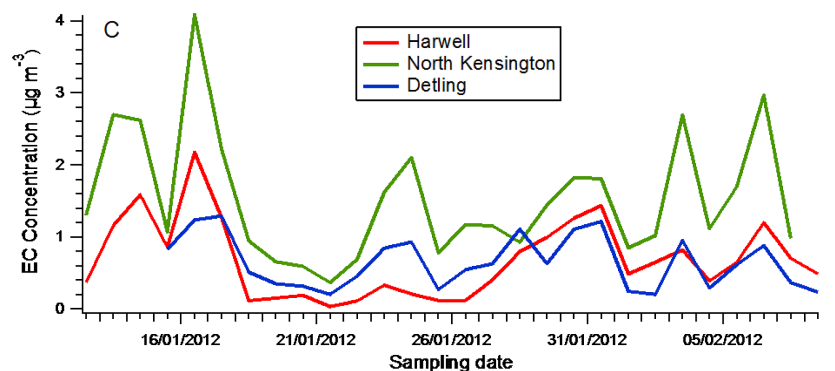

\begin{tabular}{lllll}
\hline & Method & $\mathrm{TC}_{\mathrm{nf}}(\%)$ & $\mathrm{TC}_{\mathrm{ff}}(\%)$ & $\mathrm{n}$ \\
\hline \multirow{4}{*}{ Detling } & Tracer & $62 \pm 18$ & $38 \pm 18$ & 28 \\
& Tracer* & $69 \pm 13$ & $31 \pm 13$ & 12 \\
& ${ }^{14} \mathrm{C}$ & $64 \pm 7$ & $36 \pm 7$ & 12 \\
\hline \multirow{3}{*}{ NK } & Tracer & $54 \pm 11$ & $46 \pm 11$ & 27 \\
& Tracer* & $58 \pm 9$ & $42 \pm 9$ & 6 \\
& ${ }^{4} \mathrm{C}$ & $53 \pm 6$ & $47 \pm 6$ & 6 \\
\hline \multirow{2}{*}{ Harwell } & Tracer & $72 \pm 9$ & $28 \pm 9$ & 26 \\
\hline
\end{tabular}

centrations were similar across the sites, but $\mathrm{OC}_{\mathrm{bb}}$ accounted for a higher average percentage of the total OC: $30 \pm 16$ and $23 \pm 17 \%$ at Harwell and Detling respectively compared to NK $(16 \pm 7 \%)$. At all three sites according to the tracer method, approximately $40 \%$ of the OC fraction was accounted for by the sum of biomass burning and fossil fuel

Figure 3. Time series of the concentration of (a) levoglucosan, (b) $\mathrm{OC}$, (c) EC and (d) $\mathrm{K}^{+}$at Harwell, NK and Detling. No potassium data are available for Detling.

for the ratio of levoglucosan to $\mathrm{OC}$ and an $\mathrm{OC}$ / $\mathrm{EC}$ ratio of 6 , while for vehicle emissions an OC / EC ratio of 0.58 was used. This average OC / EC ratio for vehicle emissions is notably similar to that recently determined for vehicle emissions in London (0.63) (Pant et al., 2014). The average estimated concentrations using these source ratios are shown in Fig. 4 for the three sites, with the results of the sensitivity study discussed later in this section. As expected, the concentrations of $\mathrm{EC}_{\mathrm{ff}}$ and $\mathrm{OC}_{\mathrm{ff}}$ were higher at $\mathrm{NK}(p<0.05)$, as it is an urban site with higher traffic influence compared to the rural sites. At all three sites, $\mathrm{EC}_{\mathrm{ff}}$ accounted for the majority of the $\mathrm{EC}$ fraction, indicating that the main source of $\mathrm{EC}$ was traffic emissions. Overall, the $\mathrm{OC}_{\mathrm{bb}}$ and $\mathrm{EC}_{\mathrm{bb}}$ conemissions (Fig. 4). The remaining fraction, $\mathrm{OC}_{\mathrm{SOA}}$, which includes both primary biogenic, cooking and secondary organic aerosols therefore, exceeds the sum of primary emitted biomass burning and vehicle emissions.

A more direct analysis for apportioning the fossil and nonfossil fractions of TC is the ${ }^{14} \mathrm{C}$ method, which was applied to samples from NK and Detling, with the results given in $\mathrm{Ta}-$ ble 3 . At $\mathrm{NK}$, the percentage of $\mathrm{TC}_{\mathrm{ff}}$ was higher compared to that observed at Detling (Table 3, with the daily $\mathrm{TC}_{\mathrm{nf}}$ fraction shown in Fig. S5, in the Supplement), showing the greater influence of traffic emissions at NK. As shown in Table 3, a very good agreement was observed between the percentage of contemporary $\left(\mathrm{TC}_{\mathrm{nf}}\right)$ and fossil $\left(\mathrm{TC}_{\mathrm{ff}}\right)$ carbon as determined by both the tracer and ${ }^{14} \mathrm{C}$ method, indicating that both methods were consistent in the TC apportionment. The high proportions of $\mathrm{TC}_{\mathrm{nf}}$ in $\mathrm{PM}_{2.5}$ in the range $~ 50-70 \%$ derived in this work, even for urban background (Table 3), 
are consistent with findings from elsewhere in Europe and worldwide (Heal, 2014; Hodzic et al., 2010).

To examine whether the ratios used to apportion the $\mathrm{TC}_{\mathrm{nf}}$ and $\mathrm{TC}_{\mathrm{ff}}$ were reasonable, a sensitivity study was carried out using a range of source ratios for biomass burning and vehicle emissions from the literature. Gelencsér et al. (2007) proposed minimum and maximum source ratios based on the ranges in the published data and these have been employed to estimate the uncertainty for the apportionment between contemporary and fossil carbon by the tracer method. It is worth noting that Minguillón et al. (2011) used a similar range of levoglucosan / OC ratios to assess the uncertainty of their source apportionment. Pio et al. (2011) examined $\mathrm{PM}_{2.5}$ OC / EC ratios from vehicle emissions and concluded that a range of 0.3-0.4 was typical of fresh vehicle emissions, and the lower value has also been applied to assess the uncertainty in the apportionment of vehicle emissions. Harrison et al. (2012a) recently proposed a mean levoglucosan / OC ratio of 0.09 for wood burning based on the literature, which has also been applied in this sensitivity study. Ambient ratios for biomass burning were recently determined using the nonfossil fraction of OC and EC during winter in Switzerland (Zotter et al., 2014b), and the average ratios (0.098 and 8.2 for levoglucosan / OC and OC / EC respectively) have also been included in the sensitivity analysis.

The results of this sensitivity study are presented in Table 4 , along with the values for the ratios used to apportion the contributions of fossil and non-fossil sources. The calculated $\mathrm{EC}_{\mathrm{ff}}, \mathrm{EC}_{\mathrm{bb}}, \mathrm{OC}_{\mathrm{bb}}, \mathrm{OC}_{\mathrm{ff}}$ and $\mathrm{OC}_{\mathrm{SOA}}$ concentrations for different ratios can be found in the Supplement, Table S1, while the results in Table 4 are shown in graphical form in Fig. S6. Overall, comparison between the calculated percentage $\mathrm{TC}_{\mathrm{nf}}$ and $\mathrm{TC}_{\mathrm{ff}}$ in Table 4 exhibit a wide range of values and highlights the importance of selecting the correct source ratio. The closest match to the ${ }^{14} \mathrm{C}$ results for $\mathrm{TC}_{\mathrm{nf}}$ and $\mathrm{TC}_{\mathrm{ff}}$ was found using the mean levoglucosan / OC ratio proposed by Harrison et al. (2012a) (Table 4, E), the average Swiss ambient biomass burning ratios (Table $4, \mathrm{G}$ ) and the average source ratios from Gelencsér et al. (2007) (Table 3). Therefore, it appears that with the application of average source ratios from the literature the split between contemporary and fossil carbon was reasonably estimated, though these ratios may not always accurately represent the sources (Pio et al., 2011). Inclusion of fossil secondary OC, not considered in Table 4, will also give alternative possible fits to the data.

\subsubsection{Source apportionment of $\mathrm{BC}$}

Diurnal cycles of the BC concentrations at Harwell, NK and Detling during the winter campaign measured by $2 \mathrm{~W}$ AEs are shown in Fig. 5, with the cycles for the 7W AE given in Fig. S7, in the Supplement. Similar cycles and concentrations were observed by the $2 \mathrm{~W}$ AE and $7 \mathrm{~W}$ AE at NK while at Detling the diurnal cycles were slightly different, which may have been due the instruments not being co-located. The

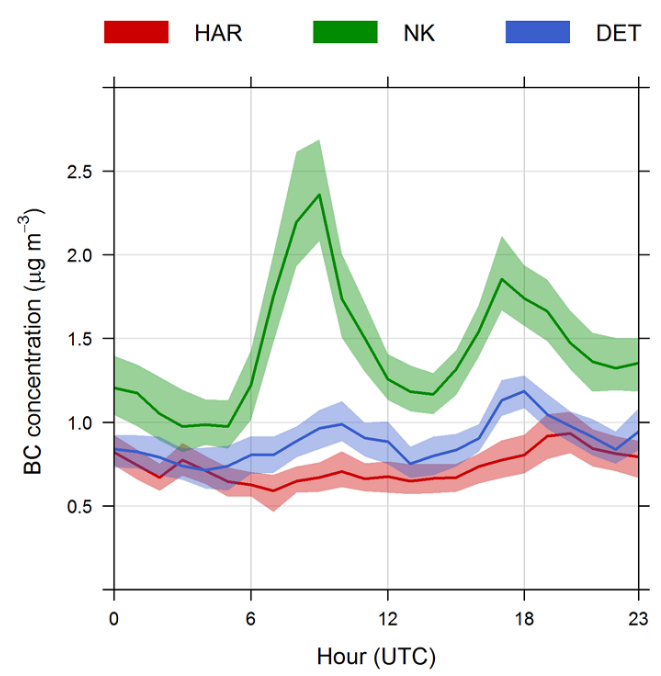

Figure 5. Mean diurnal variations in the $\mathrm{BC}$ concentrations at $880 \mathrm{~nm}$ during the winter campaign as measured by a $2 \mathrm{~W}$ AE, with the shaded areas indicating the $95 \%$ confidence intervals. Note that in the key, HAR and DET represent Harwell and Detling respectively.

classic bimodal cycle, coinciding with peak traffic times, was observed at both sites, indicating that traffic was the likely main source of BC at NK and Detling. At Harwell the diurnal cycle of $\mathrm{BC}$ was also bimodal with a similar morning peak, but the peak in concentration in the evening was observed at a later time (20:00) more associated with domestic heating. This difference in the diurnal cycles of BC suggests that local sources of biomass burning may be more influential at Harwell than the other two sites.

UVPM, defined as the difference in aethalometerdetermined concentrations for the 370 and $880 \mathrm{~nm}$ wavelength, has been proposed as a marker for biomass burning (Wang et al., 2011a). Hence the diurnal cycles of UVPM for both the $2 \mathrm{~W} \mathrm{AE}$ and $7 \mathrm{~W}$ AE were calculated and are shown in Fig. 6. All of the five cycles presented in Fig. 6 are broadly consistent with the diurnal cycles expected for wood smoke from domestic heating, with a peak in concentration in the evening. At Detling, the observed UVPM cycle is similar to the observed diurnal cycle for other biomass burning markers at Detling, including a biomass burning (BBOA) factor derived from Positive Matrix Factorization (PMF) analysis of Aerosol Mass Spectrometer data (Mohr et al., 2013). The timing of the evening concentration peak varied between the sites, with the observed concentration peak occurring earlier at the rural sites (18:00-19:00 and at 20:00 at Detling and Harwell respectively) while at NK the peak appeared later (22:00). This may point to differing source influences: the earlier peak points to more local emissions while the observed later peak at $\mathrm{NK}$ and to a lesser extent at the rural sites is suggestive of a regional influence. In addition to the evening concentration peak observed as expected 
Table 4. Average of daily percentage fraction of non-fossil and fossil TC using different source ratios. $\mathrm{OC}_{\mathrm{EC}} \mathrm{EC}_{\mathrm{veh}}$ and $\mathrm{OC} / \mathrm{EC}_{\mathrm{bb}}$ refer to the source ratio of primary vehicle and biomass burning emissions respectively. Variability shown is 1 standard deviation.

\begin{tabular}{|c|c|c|c|c|c|c|c|}
\hline \multirow[t]{2}{*}{ ID } & \multicolumn{3}{|c|}{ Source ratio applied } & \multirow[b]{2}{*}{ Site } & \multirow[b]{2}{*}{$\mathrm{TC}_{\mathrm{nf}}(\%)$} & \multirow[b]{2}{*}{$\mathrm{TC}_{\mathrm{ff}}(\%)$} & \\
\hline & Levoglucosan / OC & $\mathrm{OC} / \mathrm{EC}_{\mathrm{veh}}$ & $\mathrm{OC} / \mathrm{EC}_{\mathrm{bb}}$ & & & & \\
\hline \multirow[t]{2}{*}{ A } & 0.136 & 0.58 & 6 & Detling & $62 \pm 18$ & $38 \pm 18$ & Average source ratio \\
\hline & & & & NK & $54 \pm 11$ & $46 \pm 11$ & Gelencsér et al. (2007) \\
\hline \multirow[t]{2}{*}{ B } & 0.07 & 0.3 & 3 & Detling & $83 \pm 13$ & $17 \pm 13$ & Min. source ratio \\
\hline & & & & NK & $70 \pm 9$ & $30 \pm 9$ & \\
\hline \multirow[t]{2}{*}{$\mathrm{C}$} & 0.17 & 1 & 10 & Detling & $48 \pm 23$ & $52 \pm 23$ & Max. source ratio \\
\hline & & & & NK & $39 \pm 14$ & $61 \pm 14$ & \\
\hline \multirow[t]{2}{*}{$\mathrm{D}$} & 0.136 & 0.3 & 6 & Detling & $69 \pm 14$ & $31 \pm 14$ & Pio et al. (2011) \\
\hline & & & & NK & $62 \pm 9$ & $38 \pm 9$ & $\mathrm{OC} / \mathrm{EC}_{\mathrm{veh}}$ \\
\hline \multirow{2}{*}{$\mathrm{E}$} & 0.09 & 0.58 & 6 & Detling & $65 \pm 17$ & $35 \pm 17$ & Harrison et al. (2012a) \\
\hline & & & & NK & $55 \pm 11$ & $45 \pm 11$ & Levoglucosan / OC \\
\hline \multirow[t]{2}{*}{$\mathrm{F}$} & 0.09 & 0.3 & 6 & Detling & $71 \pm 17$ & $29 \pm 14$ & \\
\hline & & & & NK & $63 \pm 9$ & $37 \pm 9$ & \\
\hline \multirow[t]{2}{*}{ G } & 0.098 & 0.58 & 8.2 & Detling & $62 \pm 20$ & $38 \pm 18$ & Swiss biomass burning ratios \\
\hline & & & & NK & $54 \pm 11$ & $46 \pm 11$ & Zotter et al. (2014b) \\
\hline
\end{tabular}

Note: $\mathrm{TC}_{\mathrm{nf}}=\mathrm{OC}_{\mathrm{bb}}+\mathrm{EC}_{\mathrm{bb}}+\mathrm{OC}_{\mathrm{SOA}}$ and $\mathrm{TC}_{\mathrm{ff}}=\mathrm{EC}_{\mathrm{ff}}+\mathrm{OC}_{\mathrm{ff}}$

in the UVPM cycle at NK for both instruments, there was also a peak at around 07:00, suggesting a traffic influence in the observed UVPM concentrations at NK. Furthermore, the UVPM and levoglucosan concentrations were found to be correlated at all sites ( $r^{2}$ between 0.8 and 0.9). Overall, based on the diurnal cycles for UVPM presented in Fig. 6, it suggests that UVPM may be a useful qualitative marker for wood smoke in areas where traffic emissions are not dominant, in agreement with Harrison et al. (2013).

Another approach to apportioning the contributions of wood smoke and traffic emission to the observed BC concentrations is the two-component aethalometer model (Sandradewi et al., 2008a, b), which was applied to the $7 \mathrm{~W} \mathrm{AE}$ data. The concentrations of $\mathrm{BC}_{\text {tr }}$ at both sites were well correlated with $\mathrm{NO}_{\mathrm{x}}\left(r^{2}\right.$ of 0.92 and 0.65 for NK and Detling respectively) and demonstrated higher correlations than between $\mathrm{BC}_{\mathrm{wb}}$ and $\mathrm{NO}_{\mathrm{x}}\left(r^{2}\right.$ of 0.57 and 0.45 for $\mathrm{NK}$ and Detling respectively). At Detling, the concentrations of $\mathrm{BC}_{\mathrm{wb}}$ recorded a higher correlation with levoglucosan concentrations ( $r^{2}$ of 0.69$)$ compared to $\mathrm{BC}_{\mathrm{tr}}\left(r^{2}\right.$ of 0.41$)$, as expected. A similar trend was also observed at $\mathrm{NK}$, with $\mathrm{BC}_{\mathrm{wb}}$ demonstrating a higher correlation with levoglucosan $\left(r^{2}\right.$ of 0.95$)$ than $\mathrm{BC}_{\mathrm{tr}}\left(r^{2}\right.$ of 0.80$)$. The high correlation observed between $\mathrm{BC}_{\text {tr }}$ and levoglucosan at $\mathrm{NK}$ is surprising and may be due to dominance of traffic emissions in London.

Notable differences were also observed in the diurnal cycles of the $\mathrm{BC}_{\mathrm{wb}}$ and $\mathrm{BC}_{\mathrm{tr}}$ concentrations at $\mathrm{NK}$ and Detling as shown in Fig. 7. The diurnal cycles were as expected for $\mathrm{BC}_{\text {tr }}$ at both sites, exhibiting a bimodal cycle as for traffic emissions. However, at Detling the $\mathrm{BC}_{\text {tr }}$ peak in the morning is broader and the evening peak earlier than would normally be expected for a local traffic source; however the $\mathrm{NO}_{\mathrm{x}}$ di- urnal cycle also demonstrated an evening peak at the same time. Differences were observed in the $\mathrm{BC}_{\mathrm{wb}}$ diurnal cycles at Detling and NK (Fig. 7). At Detling, a peak in concentration centred on 20:00 was observed, which is typical for emissions from domestic heating. Meanwhile, the flat diurnal cycle in $\mathrm{BC}_{\mathrm{wb}}$ concentrations observed at $\mathrm{NK}$ is suggestive of regional rather than local sources. Overall, the estimated concentrations of wood smoke differed between the methods and these differences are examined in the next section.

\subsubsection{Comparison of the estimated contributions from biomass burning by the different methods}

Overall as shown in Fig. 4 and Table 5, the main source of both $\mathrm{BC}$ and $\mathrm{EC}$ was traffic emissions as opposed to biomass burning; however, the relative contributions of each source varied depending on the method employed and applied source ratio. $\mathrm{EC}_{\mathrm{bb}}$ accounted for on average $24 \pm 16$, $7 \pm 2$ and $14 \pm 12 \%$ of the total EC at Harwell, NK and Detling respectively. For the organic fraction, the relative contribution of biomass burning also varied and was generally higher than that from fossil fuel emissions at the rural sites but not at NK (Fig. 4). Using the average conversion factor for levoglucosan to wood smoke particle mass of 11.2 adopted by Harrison et al. (2012a), the mean concentrations of wood smoke mass were calculated to be 1.0, 0.87 and $0.78 \mu \mathrm{g} \mathrm{m}^{-3}$ for Harwell, NK and Detling respectively. From the tracer method, the total biomass burning contribution, taken as the sum of the $\mathrm{EC}_{\mathrm{bb}}$ and $\mathrm{OM}_{\mathrm{bb}}\left(\mathrm{OC}_{\mathrm{bb}}\right.$ converted to organic matter by conversion factor of 1.6; Aiken et al., 2008), was 1.2, 1.0 and $0.88 \mu \mathrm{g} \mathrm{m}^{-3}$ for Harwell, NK and Detling respectively. The wood smoke mass concentra- 

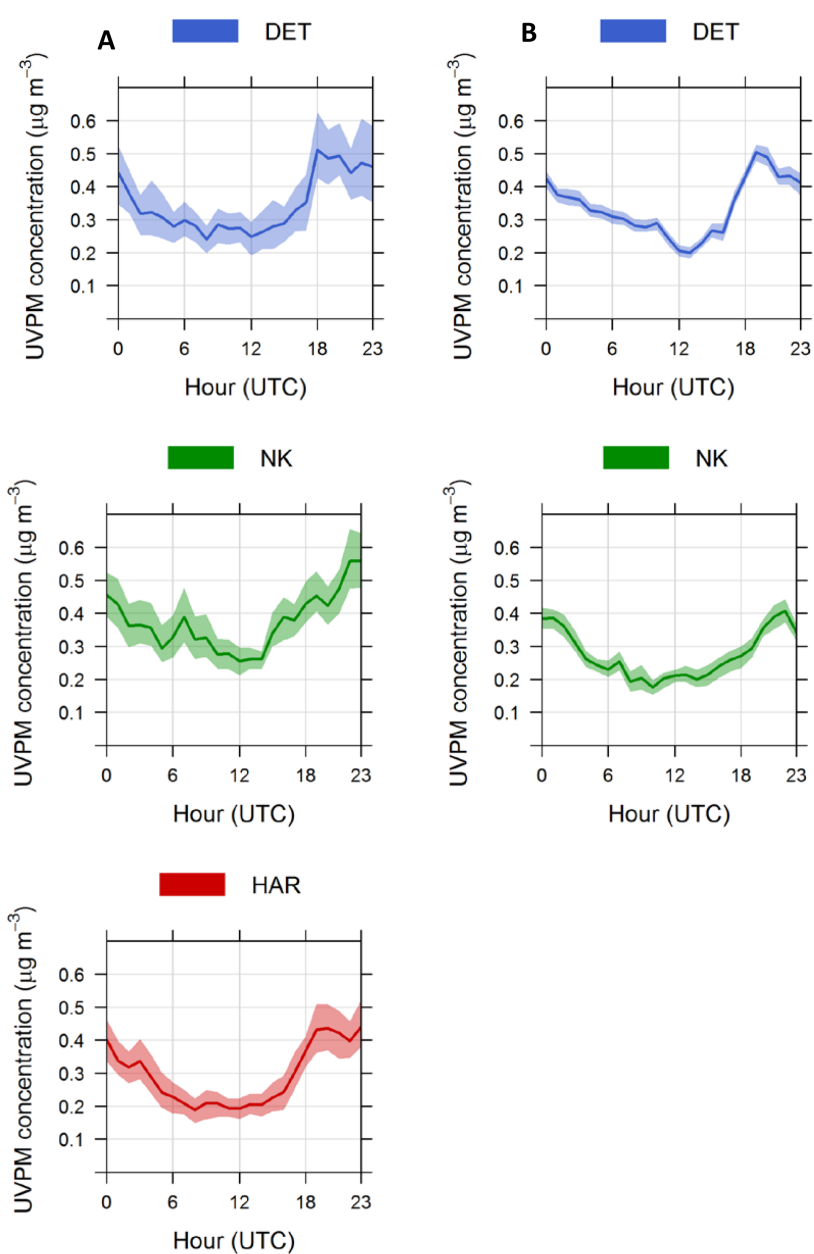

Figure 6. Mean diurnal cycles of UVPM during the winter campaign as determined by $2 \mathrm{~W}$ AEs (column A) and 7W AEs (column B) for the sites where the data were available. Shaded areas indicate the $95 \%$ confidence intervals. In the key, HAR and DET represents Harwell and Detling respectively.

tions as determined by both the levoglucosan conversion factor and the tracer method were notably similar.

The two-component aethalometer model determined the contribution of wood burning to be an average of $15 \pm 12$ and $30 \pm 13 \%$ of the BC at NK and Detling respectively. Fuller et al. (2014) found that during December and January of 20092011, wood burning accounted for an average of $23 \%$ of BC at $\mathrm{NK}$, higher than the average found in the current work at NK though within the associated variability. The difference is probably attributable to interannual variations in concentration. In this study, the $\mathrm{BC}_{\mathrm{wb}}$ followed the expected trend of higher contributions at the rural compared to the urban site, as also observed for $\mathrm{EC}_{\mathrm{bb}}$. However, the percentage contributions determined by the aethalometer model were higher than that observed for the tracer model for $\mathrm{EC}_{\mathrm{bb}}$ (Table 5). The assumptions in the tracer method and aethalometer model are constant source composition and $\alpha$ respectively. How-
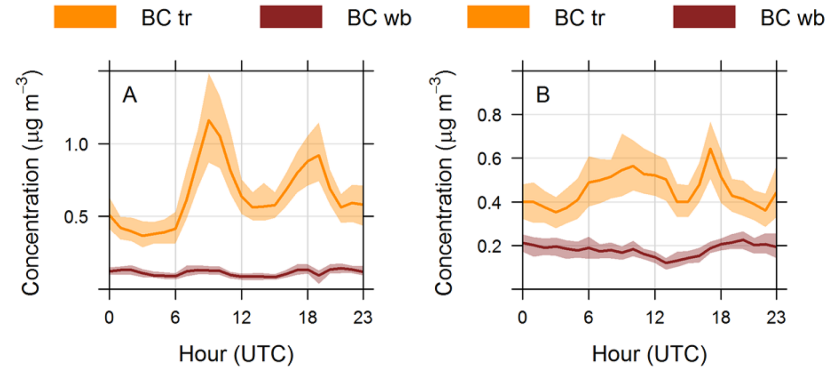

Figure 7. Mean diurnal cycle of concentration of $\mathrm{BC}_{\mathrm{wb}}$ and $\mathrm{BC}_{\mathrm{tr}}$ at $880 \mathrm{~nm}$ during the winter campaign at NK (a) and Detling (b) derived from the aethalometer model. The shaded areas represent the $95 \%$ confidence interval. Note the different $y$ axis scales used between panels.

Table 5. Percentage contributions of biomass burning and traffic emissions to total EC or BC concentration at $880 \mathrm{~nm}$ as determined by the tracer method and aethalometer model respectively. Variability shown is 1 standard deviation. Note NA means not available.

\begin{tabular}{lllll}
\hline & $\mathrm{EC}_{\mathrm{bb}}$ & $\mathrm{BC}_{\mathrm{wb}}$ & $\mathrm{EC}_{\mathrm{ff}}$ & $\mathrm{BC}_{\mathrm{tr}}$ \\
\hline Harwell & $24 \pm 16 \%$ & $\mathrm{NA}$ & $76 \pm 16 \%$ & $\mathrm{NA}$ \\
$\mathrm{NK}$ & $7 \pm 2 \%$ & $15 \pm 12 \%$ & $93 \pm 2 \%$ & $85 \pm 12 \%$ \\
Detling & $14 \pm 16 \%$ & $30 \pm 13 \%$ & $82 \pm 20 \%$ & $70 \pm 13 \%$ \\
\hline
\end{tabular}

ever, the $\alpha$ for wood burning is highly variable, ranging at least from 1.4 to 2.2 and has been shown to be dependent on variables such as the fuel and amount of atmospheric aging (Saleh et al., 2013; Kirchstetter et al., 2004). Therefore the applied $\alpha$ for wood burning may not accurately represent the biomass burning aerosols across the sites in this study, possibly resulting in higher calculated contributions. Similarly, the source composition for biomass burning $\left(\mathrm{OC} / \mathrm{EC}_{\mathrm{bb}}\right.$ and levoglucosan / OC) is also variable and has been shown to have wide range, which influences the calculated $\mathrm{EC}_{\mathrm{bb}}$ percentage contributions, ranging from 3 to 32 and 6 to $50 \%$ of the total $\mathrm{EC}$ at NK and Detling respectively (Tables 5 and S1). From Table 5, the closest match for $\mathrm{EC}_{\mathrm{bb}}$ to the $\mathrm{BC}_{\mathrm{wb}}$ percentage contributions was found using the mean levoglucosan / OC and $\mathrm{OC} / \mathrm{EC}_{\mathrm{veh}}$ and minimum OC / $\mathrm{EC}_{\mathrm{bb}}$ (Table 4, F). However, this combination of source ratios did not match ${ }^{14} \mathrm{C}$ source apportionment results as well as other combinations (see Table 4). There were no combinations in the sensitivity analysis in Table 4 that were able to closely match both the ${ }^{14} \mathrm{C}$ and aethalometer model source apportionment and this may be due to the presence of a small fraction of fossil secondary OC. Just as for $\alpha_{\mathrm{wb}}$, these source ratios may not have been selected appropriately for the study and thus the differences between the aethalometer model and tracer method may be due to the uncertainties in the applied source ratios. 
Table 6. Average of daily results for selected ratios. Variability shown is 1 standard deviation. Note NA means not available.

\begin{tabular}{llll}
\hline & Levoglucosan $/ \mathrm{K}^{+}$ & Levoglucosan / OC & OC / EC \\
\hline Harwell & $1.1 \pm 0.14$ & $0.05 \pm 0.02$ & $3.9 \pm 1.8$ \\
NK & $0.73 \pm 0.09$ & $0.02 \pm 0.01$ & $2.3 \pm 0.8$ \\
Detling & NA & $0.03 \pm 0.02$ & $3.2 \pm 1.5$ \\
\hline
\end{tabular}

\subsection{Identification of the sources of biomass burning during the winter campaign}

\subsubsection{Diagnostic ratios}

There have been a number of diagnostic ratios utilised to differentiate between the sources of biomass burning including the ratio of levoglucosan to both $\mathrm{OC}$ and $\mathrm{K}^{+}$(Harrison et al., 2012a; Minguillón et al., 2011; Reche et al., 2012). While there are a number of sources of $\mathrm{OC}$ in an urban environment in addition to biomass burning (e.g. vehicle emissions and cooking), observed correlations between levoglucosan and OC in wood smoke for different fuels suggest that its ratio can be used to determine the source (Sullivan et al., 2008). Average values for the diagnostic ratios, levoglucosan / OC and levoglucosan $/ \mathrm{K}^{+}$at each site are given in Table 6. At the three sites the average ratio of levoglucosan / OC was similar and is comparable to the characteristic ratio determined for long-range transport of biomass burning in Spain $(0.05 \pm 0.01)$ (Reche et al., 2012). This, therefore, suggests that the major source was regional biomass burning at all of the sites.

Furthermore, the observed high correlations between levoglucosan and $\mathrm{OC}$ at all the sites $\left(r^{2}\right.$ of $\left.0.71-0.88\right)$, along with the majority of the OC being found to be secondary in origin in Sect. 3.3.1, suggest a common regional source, possibly including a contribution from mainland Europe (Charron et al., 2013) for both levoglucosan and hence for $\mathrm{OC}_{\mathrm{bb}}$.

The levoglucosan $/ \mathrm{K}^{+}$ratios were determined by gradient to reduce the impact of other sources of $\mathrm{K}^{+}$, such as airborne sea salt and crustal material particles. A higher gradient was observed at Harwell $(1.1 \pm 0.14)$ than at NK $(0.73 \pm 0.09)$. Traditional fires (e.g. fireplaces, woodstoves and garden bonfires) have been shown to have a higher levoglucosan $/ \mathrm{K}^{+}$ ratio compared to more modern heaters due their higher burn efficiency (Harrison et al., 2012a; Heringa et al., 2011; Khalil and Rasmussen, 2003). The results are suggestive of the use of more efficient devices in NK, consistent with it being located in a smoke control area where the use of fireplaces and woodstoves is controlled.

At all of the sites, the concentrations of levoglucosan and $\mathrm{K}^{+}$showed some temperature dependence, with the lowest concentrations observed during the warmer periods. However, above about $5{ }^{\circ} \mathrm{C}$ the concentrations did not appear to be as dependent on temperature and thus the levoglucosan $/ \mathrm{K}^{+}$ was largely unaffected by temperature. Higher concentra- tions during weekends compared to weekdays are likely to be indicative of discretionary or recreational wood burning (Fuller et al., 2014); to determine if this influenced the observed ratios, weekend and weekday levoglucosan $/ \mathrm{K}^{+}$gradients were compared. These plots are shown in the Supplement Fig. S8, with the weekday and weekend gradients similar at Harwell. In contrast, at NK, there was a difference in the observed gradients for the weekend (1.35) compared to weekday (0.57). The higher gradient on the weekend suggests more influence from recreational burning in fireplaces during the weekend in London compared to the rural sites, where fireplaces may be utilised more throughout the week as a means of domestic heating. However, the small number of weekend samples $(n=8)$ limits the conclusions that can be drawn in this regard.

Overall, the levoglucosan $/ \mathrm{K}^{+}$ratios are low compared to most published data directly measured at the sources (e.g. fireplaces) (Caseiro et al., 2009; Puxbaum et al., 2007) but NK and Harwell were within the range reported by Harrison et al. (2012a) for ambient measurements in the UK. NK had a higher levoglucosan $/ \mathrm{K}^{+}(0.73 \pm 0.01)$ in the current study compared to the ratio of 0.15 observed by Harrison et al. (2012a). The higher ratio observed in the present work may be due to more influence from recreational burning at NK due to the colder winter. Previous work in London also found higher concentrations of wood burning tracers on weekends, which was attributed to secondary or recreational domestic heating (Fuller et al., 2014) supporting the trends observed in the current work for the levoglucosan $/ \mathrm{K}^{+}$ratio. Thus, based on the diagnostic ratios it appears that there was a contribution from local sources dependent somewhat on ambient temperature, on top of a regional background. Therefore, in the next section CPF analysis was applied to the $\mathrm{BC}$ data sets at Harwell, NK and Detling during the winter campaign to analyse whether local or regional sources were the largest contributors to biomass smoke.

\subsubsection{Direction of significant biomass burning contributions}

CPF analysis was applied to the aethalometer data sets from the winter campaign in order to find the direction of highest contributions at each site to aid the source identification. In Fig. 8, CPF analysis of the $\mathrm{BC}$ concentrations is presented as polar plots and indicates likely main sources at each site. At NK the highest $\mathrm{BC}$ contributions were associated with low wind speeds (Fig. 8), which suggests that local emissions are the main source. This, along with the diurnal cycles for BC (Fig. 5), further indicates that vehicle emissions were the main source of BC. Figure 8 also shows high contributions to the east of Harwell: in this direction lie the village of Chilton and the A34 (both $2 \mathrm{~km}$ ). Charron et al. (2013) observed a similar trend for EC concentrations and attributed it to both local traffic emissions from the A34 and also regional sources from mainland Europe. Studies have shown that the 
Detling

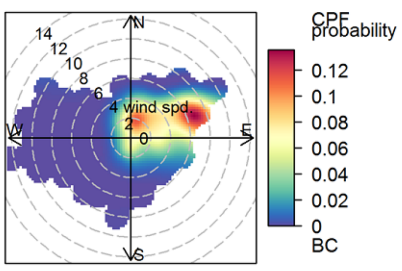

N. Kensington

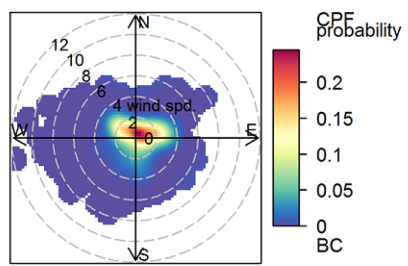

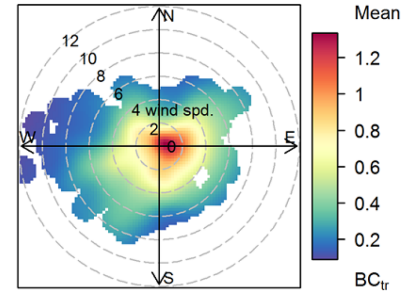

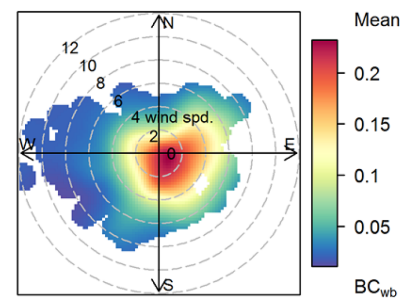

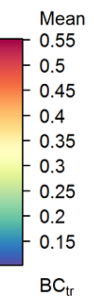

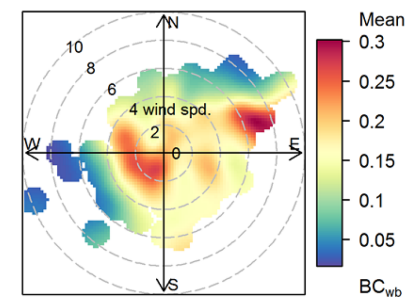

Figure 9. Polar plots of the mean concentration $\left(\mu \mathrm{g} \mathrm{m}^{-3}\right)$ of $\mathrm{BC}$ from traffic $\left(\mathrm{BC}_{\mathrm{tr}}\right)$ and wood burning $\left(\mathrm{BC}_{\mathrm{wb}}\right)$ calculated by the twocomponent aethalometer model at North Kensington (top row) and Detling (bottom row) for the winter campaign. Wind speed is in $\mathrm{ms}^{-1}$.

levels of BC and vehicle emissions diminish to background levels within $150 \mathrm{~m}$ of a road (Massoli et al., 2012; Zhu et al., 2004), and thus the A34 was probably too far away to have a strong influence. Therefore, there was probably a regional background of $\mathrm{BC}$, with contributions from local domestic heating (Fig. 8). A regional influence was also evident at Detling, with the highest contributions to the BC concentrations associated with high wind speeds from the east, in agreement with that observed in Harwell and probably influenced by advection from mainland Europe (Charron et al., 2013). High contributions were also associated with low wind speeds in Detling (Fig. 8), indicative of an additional local source of $\mathrm{BC}$ along with the regional source.

Polar plots of the mean concentrations of $\mathrm{BC}_{\mathrm{wb}}$ and $\mathrm{BC}_{\mathrm{tr}}$ concentrations were calculated in order to further analyse whether the aethalometer model could distinguish between the two sources. At Detling different source directions were observed for the two components; however, at NK the $\mathrm{BC}_{\mathrm{wb}}$ and $\mathrm{BC}_{\text {tr }}$ polar plots were similar (Fig. 9). In Fig. 9, the polar plot for $\mathrm{BC}_{\mathrm{tr}}$ at $\mathrm{NK}$ showed a slight trend in direction of the closest road ( $<100 \mathrm{~m}$ to the east) and further indicates local traffic emissions as the source. In contrast, at Detling the $\mathrm{BC}_{\mathrm{tr}}$ polar plot (Fig. 9) indicated little influence from the closest road, which was $150 \mathrm{~m}$ to the south and thus unlikely to have a large influence (Massoli et al., 2012; Zhu et al., 2004). Rather, the highest concentrations were in the direction of central London, suggesting that emissions from London may be a larger source of $\mathrm{BC}_{\mathrm{tr}}$ at Detling. Different source contributions between NK and Detling were also observed for $\mathrm{BC}_{\mathrm{wb}}$ (Fig. 9). From Fig. 9, the $\mathrm{BC}_{\mathrm{wb}}$ polar plots indicated that local sources were the main source of $\mathrm{BC}_{\mathrm{wb}}$ at North Kensington, whereas there were both local and regional influ- ences at Detling. The high concentrations of $\mathrm{BC}_{\mathrm{wb}}$ at Detling (Fig. 9) at low wind speeds to the south/south-west may be indicative of emissions from nearby villages. The highest concentrations were at high wind speeds to the east at Detling (Fig. 9), which is further indication of a strong regional biomass burning source of $\mathrm{BC}$ at the sites.

\section{Long-term measurements at the BT Tower}

To examine the influence of regional sources on the levels of air pollution it is necessary to distinguish between local and regional contributions. One method that has been used previously is to sample from an elevated site such as the BT tower (160 m a.g.1.) (Harrison et al., 2012b). The atmosphere at the tower height, under certain meteorological conditions, can become "de-coupled" from local sources at the surface when the top of the planetary boundary layer is below that of the elevated site. During these times of de-coupling, local sources will not be contributing appreciably to the observed particles at the elevated location and so regional sources will be the major contributor, allowing for characteristics of these regional particles to be investigated. Previous measurements at the BT tower in central London demonstrated that frequently at night the turbulent mixing height (TMH) can drop below the top of the tower (Barlow et al., 2011), indicating that the tower is an ideal location for analysing regional sources of airborne particles during these de-coupling periods. Because such periods mainly occur during night-time hours, the derived results will reflect the night-time situation, although the 

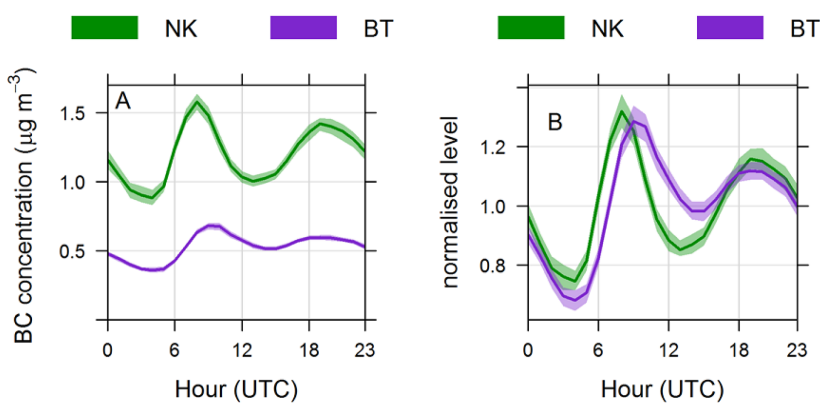

Figure 10. Mean diurnal cycles of the mean (a) and normalised (b) $\mathrm{BC}$ concentrations $(880 \mathrm{~nm})$ over the whole sampling period at the London sites. For plot $\mathrm{B}$ the values were normalised to the mean. Note $\mathrm{BC}$ concentrations were measured by a $2 \mathrm{~W} \mathrm{AE}$ at $\mathrm{NK}$ and a $7 \mathrm{~W}$ AE at the BT tower, with the same correction factor applied to both instrument data sets.

regional air may have received its pollutant input largely during daytime hours.

\subsection{Sources of BC at BT}

Summary statistics for the long-term BC and gas species concentrations at NK and BT tower can be found in Table 7. The two likely major sources of BC (traffic emissions and biomass burning) in urban areas have distinct diurnal cycles; the mean diurnal variation of $\mathrm{BC}$ for the London sites for the long-term measurement period is shown in Fig. 10. At each of the sites, the normalised BC diurnal cycles (Fig. 10) demonstrated similar cycles, to that of $\mathrm{NO}_{\mathrm{x}}$ and $\mathrm{CO}$ (Fig. S9, in the Supplement), thus implicating a similar source, likely traffic emissions based on the high fraction of fossil EC found in Sect. 3.3.1. One feature of Figs. 10 and S9 is a $1 \mathrm{~h}$ lag in the morning concentration peak at the BT tower compared to the ground-level site, possibly due to the time required for the locally emitted pollutants to mix to the top of the tower (Despiau and Croci, 2007). The main difference in the diurnal cycles shown in Fig 10 was in the absolute concentrations of $\mathrm{BC}$ at each site, which varied depending on the distance from the main local source, traffic emissions. $\mathrm{BC}$ concentrations at BT tower were, on average, a factor of 2-3 times lower than at NK (Fig. 10). EC has been observed to follow similar trends in previous measurements at BT tower and NK (Harrison et al., 2012b). Concentrations of $\mathrm{BC}$ at NK and BT tower were correlated ( $r^{2}$ of 0.6 ), indicating that the urban background as represented by the NK site was the main source of pollutants at the elevated BT site.

$\mathrm{CPF}$ analysis was applied to the observed BC concentrations at NK and the BT tower for the long-term measurements to examine whether local or regional sources were the more significant contributors, with the results shown in Fig. 11; the plots are similar to those for $\mathrm{NO}_{\mathrm{x}}$ and $\mathrm{CO}$ (Fig. S10, in the Supplement). In Fig. 11, similar trends were observed at $\mathrm{NK}$ and the $\mathrm{BT}$ tower, with the highest $\mathrm{BC}$ con-
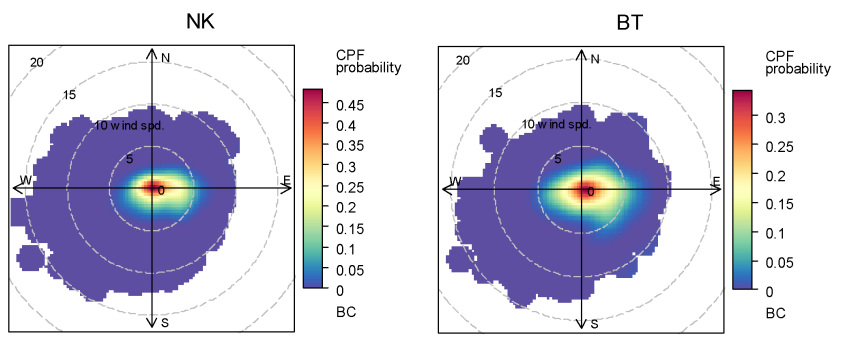

Figure 11. CPF analysis for $\mathrm{BC}$ concentrations at $880 \mathrm{~nm}$ over the whole sampling period at NK and the BT tower. Note the NK concentrations were determined with a $2 \mathrm{~W} \mathrm{AE}$ and the BT tower concentrations with a $7 \mathrm{~W}$ AE. Wind speed (wind spd) is in $\mathrm{m} \mathrm{s}^{-1}$.

centrations being associated with low wind speeds, which indicate that the major contributions were from local sources, likely vehicle emissions based on the observed diurnal cycles (Fig. 10). Overall, it appears that the main influences on BC concentrations at BT tower are local ground-level sources (traffic emissions) with some influence from regional sources, which is investigated further in subsequent sections.

\subsection{Absorption Ångstrom coefficient at the elevated (BT tower) and ground sites (NK)}

The frequency distributions of the absorption Angstrom coefficient calculated hourly for the long-term measurements at the BT tower are given in Fig. S11 (in the Supplement) and are similar to the $\alpha$ distribution for NK calculated by Harrison et al. (2013). A mode of 1.1-1.2 indicates traffic emissions as the dominant source of BC at the BT tower (Harrison et al., 2013; Sandradewi et al., 2008a). Little seasonal variation was observed in the distribution of $\alpha$ at the BT tower, with a mean $\alpha$ value of 1.1 for all seasons (Fig. S12, in the Supplement). The modest seasonal variation in the frequency distributions of $\alpha$ indicates that traffic emissions were the main source at the BT tower throughout the year. Furthermore, the $\alpha$ frequency distribution at the BT tower was not found to be dependent on wind direction. Another observation from Fig. S14 was that a considerable number of measurements had an $\alpha$ value less than 1 , as also observed by Harrison et al. (2013) at NK and elsewhere (Gyawali et al., 2009; Herich et al., 2011). The observed large number of $\alpha$ less than 1 at the BT tower may be a sampling artefact resulting from aerosol evaporation from the filters (Harrison et al., 2013). However, Gyawali et al. (2009) demonstrated that particles consisting of collapsed BC core coated with secondary organic or inorganic aerosol from vehicle emissions have an $\alpha$ less than 1 ; thus the presence of slightly aged vehicle emissions may also explain the observed large number of $\alpha$ less than 1 at the BT tower.

As 7W AE data were only available at NK during the summer and winter IOPs, the distribution of hourly $\alpha$ values was calculated for these two periods to allow direct com- 
Table 7. Summary statistics of the long-term measurements at NK and the BT tower. Note the values given for 7W AE at NK are the combined data from summer and winter campaigns. Note NA means not available.

\begin{tabular}{llllllll}
\hline & & $\mathrm{BC} 7 \mathrm{~W}$ AE & $\mathrm{BC} 2 \mathrm{~W} \mathrm{AE}$ & $\mathrm{NO}$ & $\mathrm{NO}_{2}$ & $\mathrm{CO}$ & $\mathrm{O}_{3}$ \\
\hline \multirow{5}{*}{$\mathrm{NK}$} & $\mu \mathrm{g} \mathrm{m}^{-3}$ & $\mu \mathrm{g} \mathrm{m}^{-3}$ & $\mathrm{ppb}$ & $\mathrm{ppb}$ & $\mathrm{ppm}$ & $\mathrm{ppb}$ \\
\hline & Average & 1.2 & 1.17 & 18.4 & 10.4 & 0.21 & 20.1 \\
& $\mathrm{SD}$ & 1.1 & 1.11 & 11.6 & 24.5 & 0.13 & 13.2 \\
& Min. & 0 & 0 & 0 & 0 & 0 & 0 \\
& Max. & 24.7 & 15.6 & 121 & 471 & 1.85 & 96 \\
& $n$ & 16386 & 50353 & 50784 & 50784 & 50791 & 51072 \\
\hline \multirow{5}{*}{ BT tower } & Average & 0.53 & & 4.9 & 16.4 & 0.18 & 23.8 \\
& SD & 0.42 & & 12.8 & 17.1 & 0.075 & 13.8 \\
& Min. & 0 & $\mathrm{NA}$ & 0 & 0 & 0 & 0 \\
& Max. & 6.23 & & 355 & 249 & 0.72 & 99.6 \\
& $n$ & 122394 & & 90247 & 72806 & 7251 & 105643 \\
\hline
\end{tabular}

parison between the ground and elevated sites, shown in Fig. 12. The shape of the frequency distributions of $\alpha$ at both sites was similar during each IOP, with a difference in the mode observed between the winter and summer IOP. During the summer IOP, the mean $\alpha$ was $1.09 \pm 0.12$ at both sites, while during the winter IOP the mean $\alpha$ was $1.19 \pm 0.15$ and $1.18 \pm 0.17$ at $\mathrm{NK}$ and $\mathrm{BT}$ tower respectively; this difference between seasons was found by one-way ANOVA to be statistically significant $(p<0.05)$.

As wood smoke has a higher $\alpha$ than traffic emissions, it points to an increased influence of wood smoke from domestic heating during the winter IOP. To examine this further, frequency distributions of $\alpha$ were determined for the day- and night-time (21:00 until 05:00 inclusive, to avoid peak traffic), as higher wood smoke contribution would be expected during the evening from domestic heating. As expected, there was no significant difference observed between day and night $\alpha$ distributions during the summer IOP due to the limited influence of domestic heating (Fig. S13 in the Supplement). During the winter IOP, different day/night trends were observed at the sites, with a shift to larger $\alpha$ values at both sites in the night (Fig. S14 in the Supplement). While the $\alpha$ frequency distribution showed a notable shift for night-times to larger values at NK in Fig. S14, a mean $\alpha$ of $1.23 \pm 0.19$ suggests that traffic emissions were the dominant factor even under these conditions (Harrison et al., 2013; Saleh et al., 2013).

\subsection{Identification of periods when the BT Tower was de-coupled from surface emissions}

The turbulent mixing height was calculated for the two IOPs and a number of occasions were identified when the TMH was below the sampling height of the aethalometer and gas monitors at the BT tower, and thus the measurements were de-coupled from surface emissions, as listed in Table S2 in the Supplement. As previously observed in London, ex-
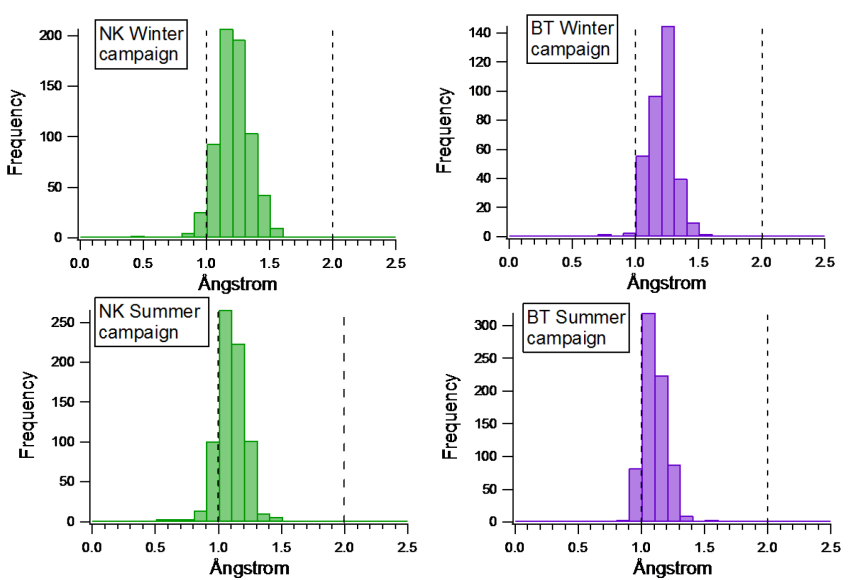

Figure 12. Histogram of Ångstrom coefficients for winter and summer campaigns at $\mathrm{NK}$ and the BT tower.

tended periods of de-coupling at the BT tower were observed at night (Barlow et al., 2011).

During only one of the de-coupling times listed in Table S2 both $\mathrm{NO}_{\mathrm{x}}$ and $\mathrm{BC}$ data were available at the $\mathrm{BT}$ tower, and the time series of the concentrations of these two pollutants are shown in Fig. 13 along with the calculated TMH during this period. This event is used to determine whether the times of de-coupling can be estimated based on the comparison between the $\mathrm{NO}_{\mathrm{x}}$ and $\mathrm{BC}$ concentration time series at the BT tower and NK. As can be seen in Fig. 13a, when the sampling platform at the BT tower is above the TMH (18:00 to 04:00), the trends in $\mathrm{NO}_{\mathrm{x}}$ concentration at the $\mathrm{BT}$ tower do not follow the trends in $\mathrm{NO}_{\mathrm{x}}$ concentration at $\mathrm{NK}$, unlike when the TMH is above the tower height. Between 18:00 on 3 February 2012 and 04:00 on 4 February 2012 when de-coupling occurred, the $\mathrm{NO}_{\mathrm{x}}$ concentration was much less variable than that at $\mathrm{NK}$, hinting at a more regional character. Furthermore, in the morning when the TMH rises above 

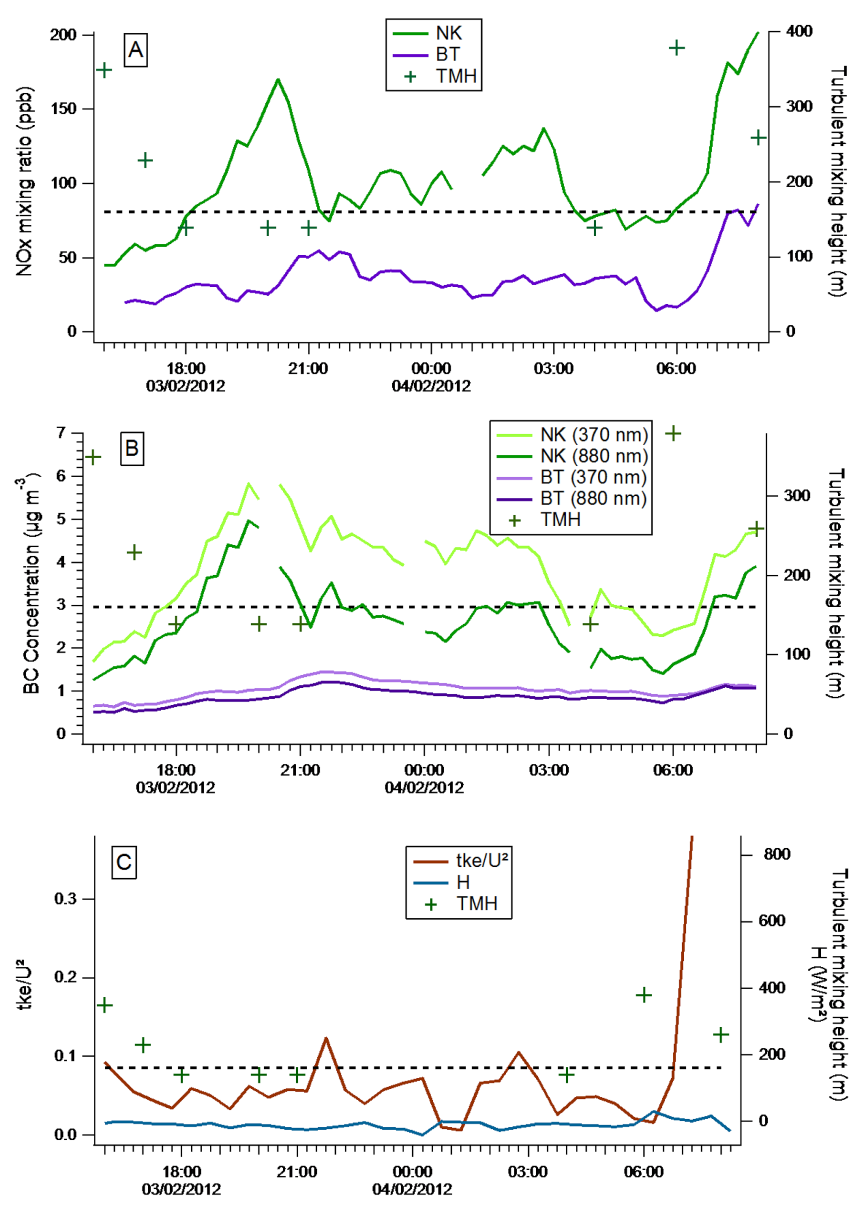

Figure 13. Time series of $\mathrm{NO}_{\mathrm{x}}$ concentration (a) and $\mathrm{BC}$ concentration measured at 370 and $880 \mathrm{~nm}$ (b) during a de-coupling event as marked by the turbulent mixing heights (TMH). For times where there are no TMH data in the figure, this is due to the turbulent layer lying below the lowest range gate of the Doppler lidar i.e. minimum resolvable TMH is $139 \mathrm{~m}$. Also shown for this de-coupling event is the sensible heat flux $(H)$ and turbulent kinetic energy normalised by the wind speed (tke/ $U^{2}$ ) as measured at the BT tower (c). Note the dashed line represents the height of the T35 sampling level of the aethalometers $(160 \mathrm{~m})$.

the tower height (06:00), the BT tower $\mathrm{NO}_{\mathrm{x}}$ concentration is observed to peak along with that at $\mathrm{NK}$ as local groundlevel emissions reach the tower platform. Similar trends are also observed for the BC concentration (Fig. 13b) and would suggest that, although there are no detectable TMH values between 22:00 and 03:00, the tower was still de-coupled during this time.

To further confirm that it was likely that the BT tower measurements were de-coupled, the sensible heat flux $(H)$ and turbulent kinetic energy normalised by the wind speed (tke/ $U^{2}$ ) measured using the sonic anemometer at $190 \mathrm{~m}$ on the BT tower are shown in Fig. 13c. As the convective boundary layer decays, and the BT Tower is thus in a residual layer, weakly stable (negative) heat fluxes should be observed and low turbulence levels would be expected. Heat flux values change sign early in the afternoon $(\sim$ 15:00) and remain negative until next morning (crossover from positive to negative values occurs at 06:00). Correspondingly, the initially enhanced turbulence $(0.142$ at 15:00) reduces to low values (around 0.05) later in the afternoon. Turbulence remains at low levels throughout the night and increases the following morning $(0.381$ at $07: 15)$. The two relatively high values observed at 21:45 and 02:45 (0.123 and 0.105 respectively) might be attributed to intermittent, locally driven turbulent events in the stable residual layer. The trends of both heat flux and turbulence agree with the mixing height data and confirm the decoupling of the BT Tower measurements during night-time when there are no mixing height data.

Overall, comparison of the observed trends in the $\mathrm{NO}_{\mathrm{x}}$ and $\mathrm{BC}$ concentrations at $\mathrm{BT}$ and $\mathrm{NK}$ allowed identification of times when the BT tower is de-coupled from ground-level emissions. Thus visual inspection of the $\mathrm{NO}_{\mathrm{x}}$ and $\mathrm{BC}$ concentrations was conducted to estimate times of de-coupling by looking for the key trends, including

- focus on night-time only, outside of peak traffic times, as this is when it is more likely to occur (Barlow et al., 2011);

- divergence in trends between NK and the BT tower, with time series at NK typically more variable than at the BT tower;

- sharp peak in concentration in the morning at the BT tower as the TMH rises above the sampler height.

By the application of these criteria, 16 additional decoupling periods were identified and are described in Table S3 (in the Supplement), along with the time series of the $\mathrm{NO}_{\mathrm{x}}$ and $\mathrm{BC}$ concentrations for selected events (Figs. S15S19 in the Supplement) demonstrating the trends that are indicative of de-coupling. Using these times of de-coupling, the influences of local and regional sources on the observed $\mathrm{BC}$ concentrations were analysed.

\subsection{Trends in the $\mathrm{BC}$ concentrations during de-coupling events}

In addition to demonstrating the changes in the TMH, Fig. 13b also revealed differences in the $\mathrm{BC}$ concentration time series as measured by the two aethalometer channels, 370 and $880 \mathrm{~nm}$, at NK and BT during the period of decoupling. While $\mathrm{BC}$ is the strongest light-absorbing component of aerosols (Moosmüller et al., 2009, and references therein), other aerosol components such as certain organic compounds have been observed to absorb light, typically at the lower visible-to-UV region of the spectrum (Zhang et al., 2013). This light-absorbing organic aerosol components, also referred to as brown carbon, are thought to arise from both 
biomass burning and secondary organic aerosols (Andreae and Gelencsér, 2006; Lack et al., 2013). Using the event in Fig. 13 when the BT tower was de-coupled from ground level emissions, the $\mathrm{BC}$ concentrations at the $\mathrm{BT}$ tower were analysed to characterise regional sources. Equally, the observed trends in the measured $\mathrm{BC}$ concentrations at NK during decoupling were likely due to local emissions with limited regional influence, and these are investigated further in the following sections.

\subsubsection{Characterisation of local BC emissions at NK during de-coupling}

In Fig. 13b, while both aethalometer channels follow the same temporal trends at $\mathrm{NK}$, the increased concentration at $370 \mathrm{~nm}$ relative to the $880 \mathrm{~nm}$ channel at around 20:00 suggests a change in contributing sources. This timing is consistent with increased contributions from biomass burning for domestic heating, while traffic emissions would be decreasing with reduced traffic flows. The time series of the calculated $\alpha$ values further demonstrates the influence of wood smoke at NK (Fig. 14). Between 20:00 and 21:00, $\alpha$ increased from 1.08 to 1.41 , which is indicative of a change in the dominant emission source from traffic $(\alpha=1)$ to wood smoke, which has a highly variable $\alpha$ ranging from 1.38 to 2 (Saleh et al., 2013; Sandradewi et al., 2008b). Furthermore, the re-emergence of traffic emission as the main source can be seen at 06:00 (when traffic counts starts to rise) as $\alpha$ dropped to 1.16 (Fig. 14).

The average $\alpha$ during the night was $1.32 \pm 0.05$, consistent with a significant biomass burning component of $\mathrm{BC}$ at NK. Similar temporal trends in the aethalometer concentrations at 370 and $880 \mathrm{~nm}$ were also observed at NK during the other winter de-coupling events (e.g. Fig. S15), while during summer de-coupling events (e.g. Figs. S17 and S18) there was little difference observed between the concentrations at 370 and $880 \mathrm{~nm}$.

\subsubsection{Characterisation of regional $\mathrm{BC}$ particles during de-coupled periods}

An increased concentration at $370 \mathrm{~nm}$ compared to $880 \mathrm{~nm}$ was also observed at the BT tower in Fig. 13, although the level of enhancement was not a large as at NK. The flat temporal trends observed at the BT tower by the aethalometer during this de-coupling period suggest regional/background levels rather than the influence of local sources. A similar flat temporal trend in $\mathrm{BC}$ concentrations was generally observed across the other de-coupling events (e.g. Figs. S16S18) though without the higher concentrations at $370 \mathrm{~nm}$. Elevated concentrations at $370 \mathrm{~nm}$ relative to the $880 \mathrm{~nm}$ channel were only observed during the winter de-coupling periods (Figs. 13 and S15), with an average increased concentration at $370 \mathrm{~nm}$ of $20-40 \%$ during these de-coupled times. With little brown carbon observed during the summer/spring, it

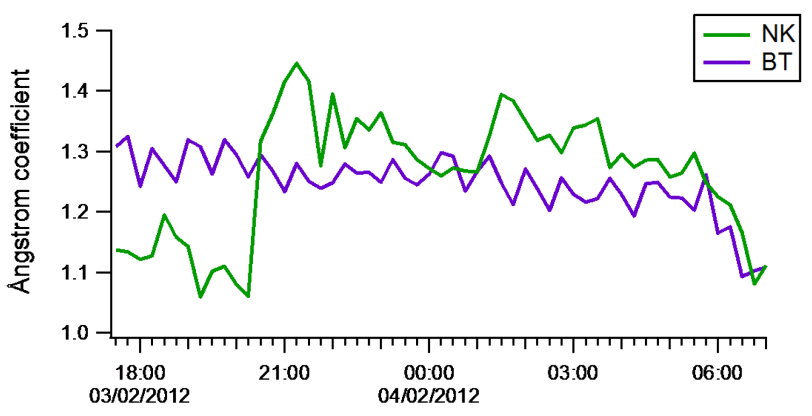

Figure 14. Time series of the calculated absorption Ångstrom coefficient during the de-coupling event from Fig. 13.

points to a seasonal effect due to biomass burning on a regional scale.

In Fig. 14, the constancy of $\alpha$ at the BT tower, with limited changes during this de-coupled period, suggests a wellmixed background of light-absorbing aerosols with a relatively uniform composition. To examine this further, the frequency distributions of $\alpha$ at the BT tower were calculated for the identified de-coupling periods and compared to the remaining nights without evidence of de-coupling (Fig. 15). Similar distributions of $\alpha$ were found with and without decoupling from surface emissions, pointing to uniform background particles that were difficult to distinguish from local sources of BC using UV wavelengths. Although most of the identified events were during summer and spring, little seasonal variation in the $\alpha$ distributions at the BT tower was observed, which suggests that regional aerosols over the whole sampling period had a similar value of $\alpha$.

It should be noted that recent studies have demonstrated that aethalometers may have difficulties distinguishing brown carbon when its levels are low compared to BC, but when there are high concentrations, for example from biomass burning, aethalometers can detect these high levels (Liu et al., 2013; Rizzo et al., 2011). Thus in the current work, apart from winter when there was a substantial amount of biomass burning from domestic heating, the levels of regional brown carbon may have been too low relative to $\mathrm{BC}$ for detection using an aethalometer.

\section{Conclusions}

By estimation of spatial distributions, sources of wood smoke during winter in London were investigated at an urban background site and two surrounding rural sites. An array of chemical species that have previously been used as biomass burning tracers were analysed to determine the wood smoke contribution. Concentrations of levoglucosan, EC, OC and $\mathrm{K}^{+}$were generally well correlated, indicating similar sources of these species and similar meteorology at the three sites. Based on the conversion factor for levoglucosan, mean wood smoke mass at Detling, NK and Harwell was 0.78, 0.87 and 

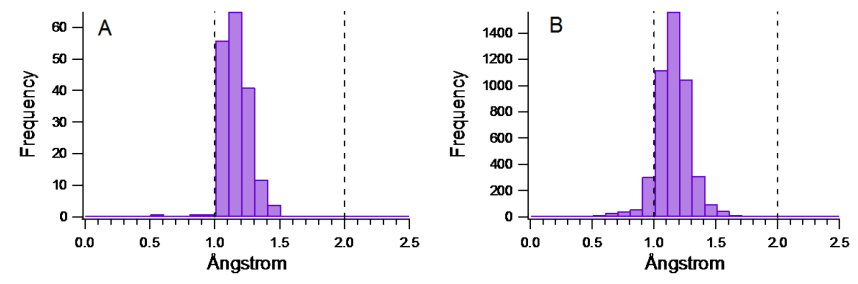

Figure 15. Histogram of hourly of Ångstrom coefficient for BT tower for (a) all de-coupling periods and (b) for the other nights.

$1.0 \mu \mathrm{g} \mathrm{m}^{-3}$ respectively. Source apportionment of the EC and OC by the tracer method of Gelencsér et al. (2007) was found to give reasonable estimation of the $\mathrm{TC}_{\mathrm{nf}}$ and $\mathrm{TC}_{\mathrm{ff}}$ based on comparison to the ${ }^{14} \mathrm{C}$ method results. The choice of source ratios used in the tracer method was found to be critical, with the averages of published data giving the most consistent split between $\mathrm{TC}_{\mathrm{nf}}$ and $\mathrm{TC}_{\mathrm{ff}}$. At all the sites, biomass burning was found to be the smallest of the major sources of primary $\mathrm{OC}$ and $\mathrm{EC}$, with the largest source of EC found to be traffic emissions, while for OC the dominant fraction likely included contributions from secondary organic aerosols (including SOA from biomass smoke), primary biogenic and cooking sources.

Similar trends to EC were observed in the source apportionment of $\mathrm{BC}$, though higher percentage contributions of wood burning were determined using the aethalometer model but were within the uncertainties associated with the tracer method. The higher percentage contributions of wood burning determined by the aethalometer model were possibly due to the chosen $\alpha$, which might not perfectly represent the wood burning conditions, wood types used and atmospheric processing in this study. The observed diurnal cycles of $\mathrm{BC}_{\mathrm{wb}}$ differed between $\mathrm{NK}$ and Detling, with the former demonstrating a flat diurnal cycle indicative of regional background while the cycle at Detling was more characteristic of domestic wood burning. Generally, apart from at NK, the diurnal cycles for UVPM were broadly consistent with expected trends for domestic heating emissions and suggest that UVPM may be a useful qualitative marker for wood smoke in areas where traffic emissions are not dominant, in agreement with a previous work (Harrison et al., 2013).

At all the sites, CPF analysis indicated high contributions from local sources, notably at NK. Peaks in the levoglucosan and $\mathrm{K}^{+}$concentrations were observed to coincide with low ambient temperature, suggesting domestic heating as a contributing source in London. Furthermore, levoglucosan concentrations were higher in the present work compared to the previous winter, likely due to the colder temperatures resulting in increased burning for domestic heating. Thus along with diurnal cycles, these local sources were probably related to domestic heating.

Measurements aloft $(160 \mathrm{~m})$ on the BT Tower showed BC to behave similarly to $\mathrm{CO}$ (and $\mathrm{NO}_{\mathrm{x}}$ ), with concentrations following those at NK, with a time lag of about $1 \mathrm{~h}$. Examination of periods when the atmospheric boundary layer top was below the BT sampling platform allowed comparison of air polluted by ground-level emissions (measured at NK) with regional air (sampled at BT). This showed little difference in the absorption Ångstrom coefficient, even in winter, between the two sites, although NK showed an increase in $\alpha$ of $\mathrm{BC}$ during periods with a low boundary layer top in winter, consistent with the influence of wood burning emissions.

Overall, the inter-site correlations in concentration across southern England, the directionality shown by the polar plots and the comparison of local ground-level and regional air composition are all consistent with widespread emissions of biomass smoke across southern England and the near continent, including emissions occurring within London itself. The contribution to PM mass is significant, and any further changes in the pattern of domestic fuel usage towards greater wood burning are a matter of concern.

\section{The Supplement related to this article is available online at doi:10.5194/acp-15-3149-2015-supplement.}

Acknowledgements. The ClearfLo project was funded by the UK Natural Environment Research Council (NE/H003142/1) and was coordinated by the UK National Centre for Atmospheric Science (NCAS). We would like to thank the Sion Manning School for use of their grounds. We thank Philip Naysmith, Gordon Cook and colleagues at the Scottish Universities Environment Research Centre at East Kilbride, UK, for provision of ${ }^{14} \mathrm{C}$ values for North Kensington PM samples. Furthermore, we are grateful to Lukas Wacker (ETH Zürich, Laboratory of Ion Beam Physics) for making available ${ }^{14} \mathrm{C}$ analyses of the Detling PM samples. Raw data are available from the authors on request.

Edited by: W. Maenhaut

\section{References}

Aiken, A. C., DeCarlo, P. F., Kroll, J. H., Worsnop, D. R., Huffman, J. A., Docherty, K. S., Ulbrich, I. M., Mohr, C., Kimmel, J. R., Sueper, D., Sun, Y., Zhang, Q., Trimborn, A., Northway, M., Ziemann, P. J., Canagaratna, M. R., Onasch, T. B., Alfarra, M. R., Prevot, A. S. H., Dommen, J., Duplissy, J., Metzger, A., Baltensperger, U., and Jimenez, J. L.: O/C and OM/OC ratios of primary, secondary, and ambient organic aerosols with high-resolution time-of-flight aerosol mass spectrometry, Environ. Sci. Technol., 42, 4478-4485, 2008.

Allan, J. D., Williams, P. I., Morgan, W. T., Martin, C. L., Flynn, M. J., Lee, J., Nemitz, E., Phillips, G. J., Gallagher, M. W., and Coe, H.: Contributions from transport, solid fuel burning and cooking to primary organic aerosols in two UK cities, Atmos. Chem. Phys., 10, 647-668, doi:10.5194/acp-10-647-2010, 2010. 
Andreae, M. O. and Gelencsér, A.: Black carbon or brown carbon? The nature of light-absorbing carbonaceous aerosols, Atmos. Chem. Phys., 6, 3131-3148, doi:10.5194/acp-6-3131-2006, 2006.

Barlow, J. F., Dunbar, T. M., Nemitz, E. G., Wood, C. R., Gallagher, M. W., Davies, F., O'Connor, E., and Harrison, R. M.: Boundary layer dynamics over London, UK, as observed using Doppler lidar during REPARTEE-II, Atmos. Chem. Phys., 11, 2111-2125, doi:10.5194/acp-11-2111-2011, 2011.

Barlow, J. F., Halios, C. H., Lane, S. E., and Wood, C. R.: Observations of urban boundary layer structure during a strong urban heat island event, Environ. Fluid Mech., 15, 1-26, 2014.

Bigi, A. and Harrison R. M.: Analysis of the air pollution climate at a central urban background site, Atmos. Environ., 44, 20042012, 2010.

Bohnenstengel, S. I., Belcher, S. E., Allan, J. D, Allen, G., Bacak, A., Bannan, T. J., Barlow, J. F., Beddows, D. C. S., Bloss, W. J., Booth, A. M., Chemel, C., Coceal, O., Di Marco, C. F., Faloon, K. H., Fleming, Z., Furger, M., Geitl, J. K., Graves, R. R., Green, D. C., Grimmond, C. S. B., Halios, C., Hamilton, J. F., Harrison, R. M., Heal, M. R., Heard, D. E., Helfter, C., Herndon, S. C., Holmes, R. E., Hopkins, J. R., Jones, A. M., Kelly, F. J., Kotthaus, S., Langford, B., Lee, J. D., Leigh, R. J., Lewis, A. C., Lidster, R. T., Lopez-Hilfiker, F. D., McQuaid, J. B., Mohr, C., Monks, P. S., Nemitz, E., Ng, N. L., Percival, C. J., Prévôt, A. S. H., Ricketts, H. M. A., Sokhi, R., Stone, D., Thornton, J. A., Tremper, A. H., Valach, A. C., Visser, S., Whalley, L. K., Williams, L. R., Xu, L., Young, D. E., and Zotter, P.: Meteorology, air quality, and health in London: The ClearfLo project, B. Am. Meteorol. Soc., doi:10.1175/bams-d-12-00245.1, 2014.

Bond, T. C., Anderson, T. L., and Campbell, D.: Calibration and intercomparison of filter-based measurements of visible light absorption by aerosols, Aerosol Sci. Technol., 30, 582-600, 1999.

Carslaw, D. C.: The openair manual - open-source tools for analysing air pollution data, Manual for version 1.0, King's College London, 2014.

Carslaw, D. C. and Ropkins, K.: openair - An R package for air quality data analysis, Environ. Modell. Softw., 27-28, 52-61, 2012.

Caseiro, A., Bauer, H., Schmidl, C., Pio, C. A., and Puxbaum, H.: Wood burning impact on $\mathrm{PM}_{10}$ in three Austrian regions, Atmos. Environ., 43, 2186-2195, 2009.

Cavalli, F., Viana, M., Yttri, K. E., Genberg, J., and Putaud, J.-P.: Toward a standardised thermal-optical protocol for measuring atmospheric organic and elemental carbon: the EUSAAR protocol, Atmos. Meas. Tech., 3, 79-89, doi:10.5194/amt-3-79-2010, 2010.

Charron, A., Birmili, W., and Harrison, R. M.: Factors influencing new particle formation at the rural site, Harwell, United Kingdom, J. Geophys. Res., 112, D14210, doi:10.1029/2007JD008425, 2007.

Charron, A., Degrendele, C., Laongsri, B., and Harrison, R. M.: Receptor modelling of secondary and carbonaceous particulate matter at a southern UK site, Atmos. Chem. Phys., 13, 1879-1894, doi:10.5194/acp-13-1879-2013, 2013.

Cohen, A. J., Anderson, R. H., Ostro, B., Pandey, K. D., Krzyzanowski, M., Künzli, N., Gutschmidt, K., Pope, A., Romieu, I., Samet, J. M., and Smith, K.: The Global Burden of Disease Due to Outdoor Air Pollution, J. Toxicol. Environ. Health, Part A, 68, 1301-1307, 2005.

Collaud Coen, M., Weingartner, E., Apituley, A., Ceburnis, D., Fierz-Schmidhauser, R., Flentje, H., Henzing, J. S., Jennings, S. G., Moerman, M., Petzold, A., Schmid, O., and Baltensperger, U.: Minimizing light absorption measurement artifacts of the Aethalometer: evaluation of five correction algorithms, Atmos. Meas. Tech., 3, 457-474, doi:10.5194/amt-3-457-2010, 2010.

Crilley, L. R., Ayoko, G. A., and Morawska, L.: First measurements of source apportionment of organic aerosols in the Southern Hemisphere, Environ. Pollut., 184, 81-88, 2014.

Crippa, M., DeCarlo, P. F., Slowik, J. G., Mohr, C., Heringa, M. F., Chirico, R., Poulain, L., Freutel, F., Sciare, J., Cozic, J., Di Marco, C. F., Elsasser, M., Nicolas, J. B., Marchand, N., Abidi, E., Wiedensohler, A., Drewnick, F., Schneider, J., Borrmann, S., Nemitz, E., Zimmermann, R., Jaffrezo, J.-L., Prévôt, A. S. H., and Baltensperger, U.: Wintertime aerosol chemical composition and source apportionment of the organic fraction in the metropolitan area of Paris, Atmos. Chem. Phys., 13, 961-981, doi:10.5194/acp-13-961-2013, 2013.

Despiau, S. and Croci, D.: Concentrations and size distributions of fine aerosol particles measured at roof level in urban zone, J. Geophys. Res.-Atmos., 112, D09212, doi:10.1029/2006JD007228, 2007.

El Haddad, I., D’Anna, B., Temime-Roussel, B., Nicolas, M., Boreave, A., Favez, O., Voisin, D., Sciare, J., George, C., Jaffrezo, J.-L., Wortham, H., and Marchand, N.: Towards a better understanding of the origins, chemical composition and aging of oxygenated organic aerosols: case study of a Mediterranean industrialized environment, Marseille, Atmos. Chem. Phys., 13, 78757894, doi:10.5194/acp-13-7875-2013, 2013.

Fahrni, S. M., Gäggeler, H. W., Hajdas, I., Ruff, M., Szidat, S., and Wacker, L.: Direct measurements of small 14C samples after oxidation in quartz tubes, Nucl. Instr. Methods Phys. Res., Sec. B, 268, 787-789, 2010.

Fuller, G. W., Sciare, J., Lutz, M., Moukhtar, S., and Wagener, S.: New Directions: Time to tackle urban wood burning?, Atmos. Environ., 68, 295-296, 2013.

Fuller, G. W., Tremper, A. H., Baker, T. D., Yttri, K. E., and Butterfield, D.: Contribution of wood burning to $\mathrm{PM}_{10}$ in London, Atmos. Environ., 87, 87-94, 2014.

Gelencsér, A., May, B., Simpson, D., Sánchez-Ochoa, A., Kasper-Giebl, A., Puxbaum, H., Caseiro, A., Pio, C., and Legrand, M.: Source apportionment of $\mathrm{PM}_{2.5}$ organic aerosol over Europe: Primary/secondary, natural/anthropogenic, and fossil/biogenic origin, J. Geophys. Res., 112, D23S04, doi:10.1029/2006JD008094, 2007.

Gyawali, M., Arnott, W. P., Lewis, K., and Moosmüller, H.: In situ aerosol optics in Reno, NV, USA during and after the summer 2008 California wildfires and the influence of absorbing and non-absorbing organic coatings on spectral light absorption, Atmos. Chem. Phys., 9, 8007-8015, doi:10.5194/acp-9-8007-2009, 2009.

Harrison, R. M., Beddows, D. C. S., Hu, L., and Yin, J.: Comparison of methods for evaluation of wood smoke and estimation of UK ambient concentrations, Atmos. Chem. Phys., 12, 82718283, doi:10.5194/acp-12-8271-2012, 2012a.

Harrison, R. M., Dall'Osto, M., Beddows, D. C. S., Thorpe, A. J., Bloss, W. J., Allan, J. D., Coe, H., Dorsey, J. R., Gallagher, 
M., Martin, C., Whitehead, J., Williams, P. I., Jones, R. L., Langridge, J. M., Benton, A. K., Ball, S. M., Langford, B., Hewitt, C. N., Davison, B., Martin, D., Petersson, K. F., Henshaw, S. J., White, I. R., Shallcross, D. E., Barlow, J. F., Dunbar, T., Davies, F., Nemitz, E., Phillips, G. J., Helfter, C., Di Marco, C. F., and Smith, S.: Atmospheric chemistry and physics in the atmosphere of a developed megacity (London): an overview of the REPARTEE experiment and its conclusions, Atmos. Chem. Phys., 12, 3065-3114, doi:10.5194/acp-12-3065-2012, 2012 b.

Harrison, R. M., Beddows, D. C. S., Jones, A. M., Calvo, A., Alves, C., and Pio, C.: An evaluation of some issues regarding the use of aethalometers to measure woodsmoke concentrations, Atmos. Environ., 80, 540-548, 2013.

Heal, M. R.: The application of carbon-14 analyses to the source apportionment of atmospheric carbonaceous particulate matter: a review, Anal. Bioanal. Chem., 406, 81-98, 2014.

Heal, M. R., Naysmith, P., Cook, G. T., Xu, S., Duran, T. R., and Harrison, R. M.: Application of $14 \mathrm{C}$ analyses to source apportionment of carbonaceous $\mathrm{PM}_{2.5}$ in the UK, Atmos. Environ., 45, 2341-2348, 2011.

Herich, H., Hueglin, C., and Buchmann, B.: A 2.5 year's source apportionment study of black carbon from wood burning and fossil fuel combustion at urban and rural sites in Switzerland, Atmos. Meas. Tech., 4, 1409-1420, doi:10.5194/amt-4-1409-2011, 2011

Heringa, M. F., DeCarlo, P. F., Chirico, R., Tritscher, T., Dommen, J., Weingartner, E., Richter, R., Wehrle, G., Prévôt, A. S. H., and Baltensperger, U.: Investigations of primary and secondary particulate matter of different wood combustion appliances with a high-resolution time-of-flight aerosol mass spectrometer, Atmos. Chem. Phys., 11, 5945-5957, doi:10.5194/acp-11-59452011, 2011.

Hodzic, A., Jimenez, J. L., Prévôt, A. S. H., Szidat, S., Fast, J. D., and Madronich, S.: Can 3-D models explain the observed fractions of fossil and non-fossil carbon in and near Mexico City?, Atmos. Chem. Phys., 10, 10997-11016, doi:10.5194/acp10-10997-2010, 2010.

Kampa, M. and Castanas, E.: Human health effects of air pollution, Environm. Pollut., 151, 362-367, 2008.

Khalil, M. A. K. and Rasmussen, R. A.: Tracers of wood smoke, Atmos. Environ., 37, 1211-1222, 2003.

Kirchstetter, T. W., Novakov, T., and Hobbs, P. V.: Evidence that the spectral dependence of light absorption by aerosols is affected by organic carbon, J. Geophys. Res.-Atmos., 109, D21208, doi:10.1029/2004JD004999, 2004.

Lack, D. A., Bahreini, R., Langridge, J. M., Gilman, J. B., and Middlebrook, A. M.: Brown carbon absorption linked to organic mass tracers in biomass burning particles, Atmos. Chem. Phys., 13, 2415-2422, doi:10.5194/acp-13-2415-2013, 2013.

Lanz, V. A., Prévôt, A. S. H., Alfarra, M. R., Weimer, S., Mohr, C., DeCarlo, P. F., Gianini, M. F. D., Hueglin, C., Schneider, J., Favez, O., D'Anna, B., George, C., and Baltensperger, U.: Characterization of aerosol chemical composition with aerosol mass spectrometry in Central Europe: an overview, Atmos. Chem. Phys., 10, 10453-10471, doi:10.5194/acp-10-10453-2010, 2010.

Liousse, C., Cachier, H., and Jennings, S. G.: Optical and thermal measurements of black carbon aerosol content in different environments: Variation of the specific attenuation cross-section, sigma $(\sigma)$, Atmos. Environ., 27, 1203-1211, 1993.
Liu, J., Bergin, M., Guo, H., King, L., Kotra, N., Edgerton, E., and Weber, R. J.: Size-resolved measurements of brown carbon in water and methanol extracts and estimates of their contribution to ambient fine-particle light absorption, Atmos. Chem. Phys., 13, 12389-12404, doi:10.5194/acp-13-12389-2013, 2013.

Massoli, P., Fortner, E. C., Canagaratna, M. R., Williams, L. R., Zhang, Q., Sun, Y., Schwab, J. J., Trimborn, A., Onasch, T. B., Demerjian, K. L., Kolb, C. E., Worsnop, D. R., and Jayne, J. T.: Pollution gradients and chemical characterization of particulate matter from vehicular traffic near major roadways: Results from the 2009 Queens College air quality study in NYC, Aerosol Sci. Technol., 46, 1201-1218, 2012.

Minguillón, M. C., Perron, N., Querol, X., Szidat, S., Fahrni, S. M., Alastuey, A., Jimenez, J. L., Mohr, C., Ortega, A. M., Day, D. A., Lanz, V. A., Wacker, L., Reche, C., Cusack, M., Amato, F., Kiss, G., Hoffer, A., Decesari, S., Moretti, F., Hillamo, R., Teinilä, K., Seco, R., Peñuelas, J., Metzger, A., Schallhart, S., Müller, M., Hansel, A., Burkhart, J. F., Baltensperger, U., and Prévôt, A. S. H.: Fossil versus contemporary sources of fine elemental and organic carbonaceous particulate matter during the DAURE campaign in Northeast Spain, Atmos. Chem. Phys., 11, 12067-12084, doi:10.5194/acp-11-12067-2011, 2011.

Mohr, C., Lopez-Hilfiker, F. D., Zotter, P., Prévôt, A. S. H., Xu, L., Ng, N. L., Herndon, S. C., Williams, L. R., Franklin, J. P., Zahniser, M. S., Worsnop, D. R., Knighton, W. B., Aiken, A. C., Gorkowski, K. J., Dubey, M. K., Allan, J. D., and Thornton, J. A.: Contribution of nitrated phenols to wood burning brown carbon light absorption in Detling, United Kingdom during winter time, Environ. Sci. Technol., 47, 6316-6324, 2013.

Moosmüller, H., Chakrabarty, R. K., and Arnott, W. P.: Aerosol light absorption and its measurement: A review, J. Quant. Spectrosc. Radiat. Transfer, 110, 844-878, 2009.

Pant, P., Yin, J., and Harrison, R. M.: Sensitivity of a Chemical Mass Balance model to different molecular marker traffic source profiles, Atmos. Environ., 82, 238-249, 2014.

Petzold, A., Kopp, C., and Niessner, R.: The dependence of the specific attenuation cross-section on black carbon mass fraction and particle size, Atmos. Environ., 31, 661-672, 1997.

Petzold, A., Ogren, J. A., Fiebig, M., Laj, P., Li, S.-M., Baltensperger, U., Holzer-Popp, T., Kinne, S., Pappalardo, G., Sugimoto, N., Wehrli, C., Wiedensohler, A., and Zhang, X.-Y.: Recommendations for reporting "black carbon" measurements, Atmos. Chem. Phys., 13, 8365-8379, doi:10.5194/acp-13-83652013, 2013.

Pio, C., Cerqueira, M., Harrison, R. M., Nunes, T., Mirante, F., Alves, C., Oliveira, C., Sanchez de la Campa, A., Artínano, B., and Matos, M.: OC / EC ratio observations in Europe: Rethinking the approach for apportionment between primary and secondary organic carbon, Atmos. Environ., 45, 6121-6132, 2011.

Puxbaum, H., Caseiro, A., Sánchez-Ochoa, A., Kasper-Giebl, A., Claeys, M., Gelencsér, A., Legrand, M., Preunkert, S., and Pio, C.: Levoglucosan levels at background sites in Europe for assessing the impact of biomass combustion on the European aerosol background, J. Geophys. Res., 112, D23S05, doi:10.1029/2006JD008114, 2007.

Qadir, R. M., Abbaszade, G., Schnelle-Kreis, J., Chow, J. C., and Zimmermann, R.: Concentrations and source contributions of particulate organic matter before and after implementation of a 
low emission zone in Munich, Germany, Environ. Pollut., 175, 158-167, 2013.

Reche, C., Querol, X., Alastuey, A., Viana, M., Pey, J., Moreno, T., Rodríguez, S., González, Y., Fernández-Camacho, R., de la Rosa, J., Dall'Osto, M., Prévôt, A. S. H., Hueglin, C., Harrison, R. M., and Quincey, P.: New considerations for PM, Black Carbon and particle number concentration for air quality monitoring across different European cities, Atmos. Chem. Phys., 11, 6207-6227, doi:10.5194/acp-11-6207-2011, 2011.

Reche, C., Viana, M., Amato, F., Alastuey, A., Moreno, T., Hillamo, R., Teinilä, K., Saarnio, K., Seco, R., Peñuelas, J., Mohr, C., Prévôt, A. S. H., and Querol, X.: Biomass burning contributions to urban aerosols in a coastal Mediterranean City, Sci. Tot. Environ., 427-428, 175-190, 2012.

Ricardo-AEA: QA / QC Data Ratification Report for the Automatic Urban and Rural Network, January-March 2013, and Intercalibration Report, Winter 2013, Report for Department for Environment, Food and Rural Affairs, The Scottish Government, The Welsh Government, The Northern Ireland Department of Environment, Ricardo-AEA/R/3382, Issue 1, UK, 2013.

Rizzo, L. V., Correia, A. L., Artaxo, P., Procópio, A. S., and Andreae, M. O.: Spectral dependence of aerosol light absorption over the Amazon Basin, Atmos. Chem. Phys., 11, 8899-8912, doi:10.5194/acp-11-8899-2011, 2011.

Ruff, M., Wacker, L., Gaggeler, H. W., Suter, M., Synal, H. A., and Szidat, S.: A gas ion source for radiocarbon measurements at 200 kV, Radiocarbon, 49, 307-314, 2007.

Ruff, M., Szidat, S., Gäggeler, H. W., Suter, M., Synal, H. A., and Wacker, L.: Gaseous radiocarbon measurements of small samples, Nucl. Instr. Methods Phys. Res., Sec. B, 268, 790-794, 2010.

Saarikoski, S. K., Sillanpää, M. K., Saarnio, K. M., Hillamo, R. E., Pennanen, A. S., and Salonen, R. O.: Impact of biomass combustion on urban fine particulate matter in central and northern Europe, Water Air Soil Poll., 191, 265-277, 2008.

Saleh, R., Hennigan, C. J., McMeeking, G. R., Chuang, W. K., Robinson, E. S., Coe, H., Donahue, N. M., and Robinson, A. L.: Absorptivity of brown carbon in fresh and photo-chemically aged biomass-burning emissions, Atmos. Chem. Phys., 13, 76837693, doi:10.5194/acp-13-7683-2013, 2013.

Sandradewi, J., Prévôt, A. S. H., Szidat, S., Perron, N., Alfarra, M. R., Lanz, V. A., Weingartner, E., and Baltensperger, U.: Using aerosol light absorption measurements for the quantitative determination of wood burning and traffic emission contributions to particulate matter, Environ. Sci. Technol., 42, 3316-3323, $2008 \mathrm{a}$.

Sandradewi, J., Prévôt, A. S. H., Weingartner, E., Schmidhauser, R., Gysel, M., and Baltensperger, U.: A study of wood burning and traffic aerosols in an Alpine valley using a multi-wavelength Aethalometer, Atmos. Environ., 42, 101-112, 2008b.

Schauer, J. J., Kleeman, M. J., Cass, G. R., and Simoneit, B. R. T.: Measurement of emissions from air pollution sources. 3. C1-C29 organic compounds from fireplace combustion of wood, Environ. Sci. Technol., 35, 1716-1728, 2001.

Schmidl, C., Marr, I. L., Caseiro, A., Kotianová, P., Berner, A., Bauer, H., Kasper-Giebl, A., and Puxbaum, H.: Chemical characterisation of fine particle emissions from wood stove combustion of common woods growing in mid-European Alpine regions, Atmos. Environ., 42, 126-141, 2008.
Simoneit, B. R. T.: Biomass burning - a review of organic tracers for smoke from incomplete combustion, Appl. Geochem., 17, 129$162,2002$.

Stuiver, M. and Polach, H. A.: Reporting of C-14 data-discussion, Radiocarbon, 19, 355-36, 1977.

Sullivan, A. P., Holden, A. S., Patterson, L. A., McMeeking, G. R., Kreidenweis, S. M., Malm, W. C., Hao, W. M., Wold, C. E., and Collett, J. L.: A method for smoke marker measurements and its potential application for determining the contribution of biomass burning from wildfires and prescribed fires to ambient $\mathrm{PM}_{2.5}$ organic carbon, J. Geophys. Res., 113, D22302, doi:10.1029/2008JD010216, 2008.

Synal, H. A., Stocker, M., and Suter, M.: MICADAS: A new compact radiocarbon AMS system, Nucl. Instr. Methods Phys. Res., Sec. B, 259, 7-13, 2007.

Szidat, S., Jenk, T. M., Gäggeler, H. W., Synal, H. A., Hajdas, I., Bonani, G., and Saurer, M.: THEODORE, a two-step heating system for the EC/OC determination of radiocarbon (14C) in the environment, Nucl. Instr. Methods Phys. Res., Sec. B, 223-224, 829-836, 2004.

Szidat, S., Jenk, T. M., Synal, H. A., Kalberer, M., Wacker, L., Hajdas, I., Kasper-Giebl, A., and Baltensperger, U.: Contributions of fossil fuel, biomass-burning, and biogenic emissions to carbonaceous aerosols in Zurich as traced by 14C, J. Geophys. Res., 111, D07206, doi:10.1029/2005JD006590, 2006.

Viana, M., Kuhlbusch, T. A. J., Querol, X., Alastuey, A., Harrison, R. M., Hopke, P. K., Winiwarter, W., Vallius, M., Szidat, S., Prévôt, A. S. H., Hueglin, C., Bloemen, H., Wåhlin, P., Vecchi, R., Miranda, A. I., Kasper-Giebl, A., Maenhaut, W., and Hitzenberger, R.: Source apportionment of particulate matter in Europe: A review of methods and results, J. Aerosol Sci., 39, 827-849, 2008.

Viana, M., Reche, C., Amato, F., Alastuey, A., Querol, X., Moreno, T., Lucarelli, F., Nava, S., Cazolai, G., Chiari, M., and Rico, M.: Evidence of biomass burning aerosols in the Barcelona urban environment during winter time, Atmos. Environ., 72, 81-88, 2013.

Wacker, L., Christl, M., and Synal, H. A.: Bats: A new tool for AMS data reduction, Nucl. Instr. Methods Phys. Res., Sec. B, 268, 976-979, 2010.

Wacker, L., Fahrni, S. M., Hajdas, I., Molnar, M., Synal, H. A., Szidat, S., and Zhang, Y. L.: A versatile gas interface for routine radiocarbon analysis with a gas ion source, Nucl. Instr. Methods Phys. Res., Sec. B, 294, 315-319, 2013.

Wagener, S., Langner, M., Hansen, U., Moriske, H.-J., and Endlicher, W. R.: Spatial and seasonal variations of biogenic tracer compounds in ambient $\mathrm{PM}_{10}$ and PM1 samples in Berlin, Germany, Atmos. Environ., 47, 33-42, 2012.

Wang, Y., Hopke, P. K., Rattigan, O. V., Xia, X., Chalupa, D. C., and Utell, M. J.: Characterization of residential wood combustion particles using the two-wavelength aethalometer, Environ. Sci. Technol., 45, 7387-7393, $2011 \mathrm{a}$.

Wang, Y., Hopke, P. K., Rattigan, O. V., and Zhu, Y.: Characterization of ambient black carbon and wood burning particles in two urban areas, J. Environ. Monitor., 13, 1919-1926, 2011 b.

Weingartner, E., Saathoff, H., Schnaiter, M., Streit, N., Bitnar, B., and Baltensperger, U.: Absorption of light by soot particles: determination of the absorption coefficient by means of aethalometers, J. Aerosol Sci., 34, 1445-1463, 2003. 
Yin, J., Harrison, R. M., Chen, Q., Rutter, A., and Schauer, J. J.: Source apportionment of fine particles at urban background and rural sites in the UK atmosphere, Atmos. Environ., 44, 841-851, 2010.

Yttri, K. E., Dye, C., Slørdal, L. H., and Braathen, O.-A.: Quantification of monosaccharide anhydrides by liquid chromatography combined with mass spectrometry: Application to aerosol samples from an urban and a suburban site influenced by small-scale wood burning, J. Air Waste Manage., 55, 1169-1177, 2005.

Zapf, A., Nesje, A., Szidat, S., Wacker, L., and Schwikowski, M.: C-14 measurements of ice samples from the Juvfonne ice tunnel, Jotunheimen, southern Norway-validation of a C-14 dating technique for glacier ice, Radiocarbon, 55, 571-578, 2013.

Zhang, X., Lin, Y.-H., Surratt, J. D., and Weber, R. J.: Sources, composition and absorption ångström exponent of light-absorbing organic components in aerosol extracts from the Los Angeles Basin, Environ. Sci. Technol., 47, 3685-3693, 2013.
Zhu, Y., Hinds, W. C., Shen, S., and Sioutas, C.: Seasonal trends of concentration and size distribution of ultrafine particles near major highways in Los Angeles Special Issue of Aerosol Science and Technology on Findings from the Fine Particulate Matter Supersites Program, Aerosol Sci. Technol., 38, 5-13, 2004.

Zotter, P., El-Haddad, I., Zhang, Y., Hayes, P. L., Zhang, X., Lin, Y.-H., Wacker, L., Schnelle-Kreis, J., Abbaszade, G., Zimmermann, R., Surratt, J. D., Weber, R., Jimenez, J. L., Szidat, S., Baltensperger, U., and Prévôt, A. S. H.: Diurnal cycle of fossil and non-fossil carbon using radiocarbon analyses during CalNex, J. Geophys. Res., 119, 6818-6835, doi:10.1002/2013JD021114, 2014a.

Zotter, P., Ciobanu, V. G., Zhang, Y. L., El-Haddad, I., Macchia, M., Daellenbach, K. R., Salazar, G. A., Huang, R.-J., Wacker, L., Hueglin, C., Piazzalunga, A., Fermo, P., Schwikowski, M., Baltensperger, U., Szidat, S., and Prévôt, A. S. H.: Radiocarbon analysis of elemental and organic carbon in Switzerland during winter-smog episodes from 2008 to 2012 -Part 1: Source apportionment and spatial variability, Atmos. Chem. Phys., 14, 1355113570, doi:10.5194/acp-14-13551-2014, 2014b. 